\title{
EVOLUÇÃO DA POPULAÇÃO BACTERIANA NA LINHA DE PRODUÇÃO DO QUEIJO MINAS FRESCAL EM UMA INDÚSTRIA DE LATICÍNIOS
}

\author{
MILENA OLIVIERI LISITA
}

\begin{abstract}
Dissertação apresentada à Escola Superior de Agricultura "Luiz de Queiroz", Universidade de São Paulo, para obtenção do título de Mestre em Ciências, Área de Concentração: Ciência e Tecnologia de Alimentos.
\end{abstract}

P I R A C I C A B A

Estado de São Paulo - Brasil

Junho - 2005 


\title{
EVOLUÇÃO DA POPULAÇÃO BACTERIANA NA LINHA DE PRODUÇÃO DO QUEIJO MINAS FRESCAL EM UMA INDÚSTRIA DE LATICÍNIOS
}

\author{
MiLENA OLIVIERI LiSITA \\ Engenheira de Alimentos
}

Orientador: Prof. Dr. ERNANI PORTO

Dissertação apresentada à Escola Superior de Agricultura "Luiz de Queiroz", Universidade de São Paulo, para obtenção do título de Mestre em Ciências, Área de Concentração: Ciência e Tecnologia de Alimentos.

P IR A C I C A B A

Estado de São Paulo - Brasil

Junho - 2005 
Dados Internacionais de Catalogação na Publicação (CIP) DIVISÃO DE BIBLIOTECA E DOCUMENTAÇÃO - ESALQ/USP

Lisita, Milena Olivieri

Evolução da população bacteriana na linha de produção do queijo minas frescal em uma indústria de lacticínios / Milena Olivieri Lisista. - - Piracicaba, 2005.

61 p. : il.

Dissertação (mestrado) - - Escola Superior de Agricultura Luiz de Queiroz, 2005.

Bibliografia.

1. Contaminação de alimentos 2. Indústria de laticínio 3. Microbiologia de alimentos 4. Pasteurização 5. Processamento de alimentos 6. Queijo 7. Saúde pública

8. Staphylococcus I. Título

CDD 637.353

"Permitida a cópia total ou parcial deste documento, desde que citada a fonte - O autor" 
Ao теu pai, Pasqualino Lisita (in memoriam), que se foi deixando muitas saudades e um grande exemplo de caráter e solidariedade a ser seguido,

Dedico. 


\section{AGRADECIMENTOS}

Agradeço imensamente à minha mãe, pelo seu amor e por todo incentivo e apoio, essenciais para realização deste trabalho.

Ao meu orientador, pelos ensinamentos, orientação, paciência e ajudas.

Ao professor e amigo Urgel por toda sua atenção, pela contribuição nas correções e por ser membro da banca da Qualificação. Aos demais membros da banca, prof. Claúdio R. Gallo e Dra. Maria Helena C. R. Passos, pelas sugestões apresentadas.

Ao meu namorado Guilherme, pela união, por todo afeto e por ter compreendido minhas ausências.

Agradeço a minha maravilhosa família: Fre (irmão), Val (cunhada) $e$ sobrinhos, Enrico e Luigi, que mesmo de longe me trazem alegria.

Aos funcionários do Departamento de Agroindústria, dentre eles: Luis, Regina Marafon, Rubão, Cecília, Rose, Jefferson, Wilsão, Márcia, Gislaine, Sidnei, $D^{a}$ Amábile e à bibliotecária Bia, agradeço toda simpatia e serviços prestados. Agradeço especialmente à Cleo pela força no laboratório e pelas conversas amigas.

Aos estagiários, Bruno e Raquel, suas ajudas e caronas (Raquel) até à indústria foram de suma importância.

Aos funcionários da indústria de laticinios, pela gentileza e ao proprietário por conceder as visitas e coletas.

Às valiosas amizades conquistadas em todo o mestrado, a começar por elas, Cláudia Irene e Miriam: obrigada pela ótima vivência e pela sincera e grande amizade. E às que moraram comigo por menos tempo mas, que também além de muito queridas, fizeram parte de um dia-a-dia divertido e saudável, 
Giselle, Mariana, Giovanna, Milena Ramires, Márcia Regina, Fabiana Curti e Flavinha.

$\grave{A}$ todos os companheiros e amigos de Vila Estudantil, principalmente a Wirifram, Aurélio, Claúdio, Juan, Junio, Maurício, Fabiana, Selma, Adriana, Henrique, Mário e Cassiano. Ao Erick, quem nunca vou esquecer de sua incrivel companhia e de todo carinho. E ao Jadson, pelo excelente convivio.

Aos raros e inesquecíveis amigos: Zé Wilson, obrigada pela ligação tão fraterna e por ser o melhor parceiro de forró; ao Ricardinho, por me levantar o ego e me divertir muito; e ao Vander, por toda consideração.

E ainda não poderia deixar de lado pessoas estimadas como Mônica, Daniela Cordeiro, Ciça, Claudia Coelho, Aninha, Oca, Farias, Vandeco, Rubén, Thaís e Paty. E à Vanessa Rosa, pelo encorajamento e pelas ajudas.

À CAVE, pela concessão de moradia durante quase todo mestrado.

Ao SENAI "Mário Dedini", em nome de Wilson Rensi, pela confiança e pelas oportunidades de trabalho. 


\section{SUMÁRIO}

Página

LISTA DE FIGURAS................................................................................ viii

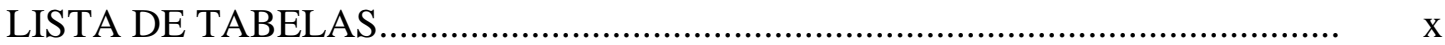

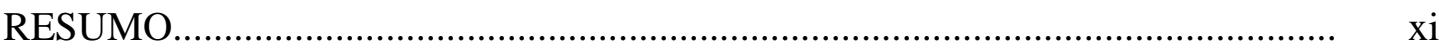

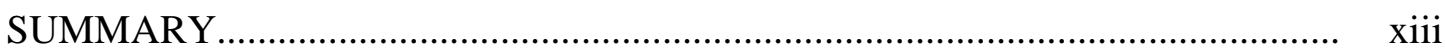

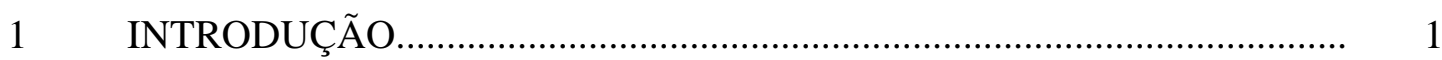

2 REVISÃO DE LITERATURA................................................................. 4

$2.1 \quad$ O queijo Minas frescal.................................................................................. 4

2.1.1 Fabricação do queijo Minas frescal.................................................................. 5

2.1.2 O leite como matéria-prima............................................................................... 8

2.2 Microrganismos mesófilos aeróbios............................................................. 9

2.3 Microrganismos psicrotróficos aeróbios............................................................ 10

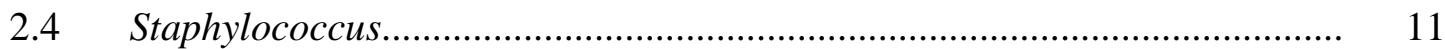

$2.5 \quad$ Coliformes totais e fecais............................................................................. 13

$3 \quad$ MATERIAL E MÉTODOS..................................................................... 16

3.1 Descrição do processamento....................................................................... 16

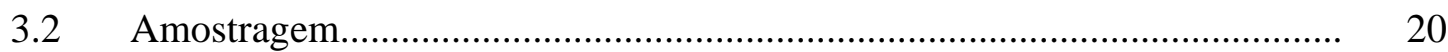

3.2.1 Amostras de leite cru e pasteurizado................................................................. 21

3.2.2 Amostras de coalhadas e queijos................................................................ 22

3.2.3 Amostras de salmoura.......................................................................... 23

3.3 Análises microbiológicas....................................................................... 23

3.3.1 Contagem total de microrganismos mesófilos aeróbios................................. 23

3.3.2 Contagem total de microrganismos psicrotróficos aeróbios.......................... 24 
3.3.3 Determinação do número mais provável (NMP) de Staphylococcus coagulase positiva

3.3.4 Contagem de Staphylococcus coagulase positiva por plaqueamento direto

3.3.5 Determinação do número mais provável (NMP) de coliformes totais e fecais

$4 \quad$ RESULTADOS E DISCUSSÃO......................................................... 28

4.1 Pasteurização.......................................................................................... 28

4.2 Tanque de coagulação..................................................................................... 34

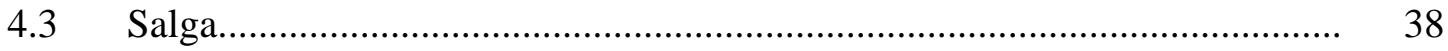

4.4 Amostragem completa ao longo da linha........................................................ 44

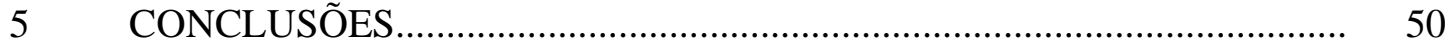

REFERÊNCIAS BIBLIOGRÁFICAS................................................................... 52 


\section{LISTA DE FIGURAS}

Página

1 Plataforma de recepção do leite e máquina de lavar os recipientes.

2 Enchimento do tanque de coagulação com o leite saindo do pasteurizador. Espuma, que é formada na superfície da coalhada, sendo jogada no chão.

3 Início da dessoragem. Soro sendo bombeado a outro tanque.

4 Enformagem

5 Fluxograma de produção do queijo Minas Frescal

6 Contagens de microrganismos mesófilos aeróbios no leite cru e no leite pasteurizado nas quatro primeiras coletas, avaliando a pasteurização.

7 Contagens de coliformes totais no leite cru e no leite pasteurizado nas quatro primeiras coletas, avaliando a pasteurização.

8 Contagens de coliformes fecais no leite cru e no leite pasteurizado nas quatro primeiras coletas, avaliando a pasteurização......

9 Contagens de microrganismos mesófilos aeróbios no leite pasteurizado, na coalhada cortada e na coalhada dessorada nas coletas 4, 5, 6 e 7, avaliando o tanque de coagulação.

10 Contagens de microrganismos mesófilos aeróbios na salmoura, no queijo antes da salga e no queijo pós salga nas coletas 8, 9 e 10, avaliando a salga..... 
11 Contagens de microrganismos psicrotróficos aeróbios na salmoura, no queijo antes da salga e no queijo pós salga nas coletas 8, 9 e 10, avaliando a salga.....

12 Contagens de microrganismos mesófilos aeróbios na coleta 11, avaliando toda linha de produção.

13 Contagens de coliformes totais na coleta 11, avaliando toda linha de produção.

14 Contagens de coliformes fecais na coleta 11, avaliando toda linha de produção. 


\section{LISTA DE TABELAS}

Página

1 Limites para o crescimento e produção de enterotoxina do S. aureus.

2 Relatos de toxinfecções alimentares causadas pela ingestão da enterotoxina estafilocóccica (Minas Gerais de 1995 a 2001).

3 Gêneros detectados e não detectados nas provas para coliformes.

4 Esquematização da amostragem

5 Contagens de microrganismos mesófilos aeróbios, coliformes totais, coliformes fecais e Staphylococcus coagulase positiva das amostras de leite cru e de leite pasteurizado.

6 Contagens de microrganismos mesófilos aeróbios, coliformes totais, coliformes fecais e Staphylococcus coagulase positiva nas amostras de leite pasteurizado, coalhada cortada e coalhada dessorada....

7 Contagens de microrganismos mesófilos aeróbios, psicrotróficos aeróbios, coliformes totais, coliformes fecais e Staphylococcus coagulase positiva nas amostras de queijos antes e após a salga e na própria salmoura.

8 Parâmetros físico-químicos do queijo Minas frescal.

9 Contagens de microrganismos mesófilos aeróbios, psicrotróficos aeróbios, coliformes totais, coliformes fecais e Staphylococcus coagulase positiva das amostras da coleta $\mathrm{n}^{\circ} 11$. 


\section{EVOLUÇÃO DA POPULAÇÃO BACTERIANA NA LINHA DE PRODUÇÃO DO QUEIJO MINAS FRESCAL EM UMA INDÚSTRIA DE LATICÍNIOS}

Autora: MILENA OLIVIERI LISITA

Orientador: Prof. Dr. ERNANI PORTO

\section{RESUMO}

A evolução da população de microrganismos mesófilos aeróbios, coliformes totais e fecais e Staphylococcus coagulase positiva foi estudada na linha de processamento do queijo Minas frescal em uma indústria de laticínios sujeita à fiscalização do Serviço de Inspeção Federal (S.I.F.). Três pontos do processamento foram avaliados individualmente: a pasteurização com amostras de leite cru e leite pasteurizado, a coagulação com amostras de leite pasteurizado, de coalhada cortada e de coalhada dessorada e a salga com amostras de queijos antes e depois da salga e da salmoura. A contagem de microrganismos psicrotróficos aeróbios foi incluída na etapa de salga porque é feita sob refrigeração. E depois foram coletadas amostras de um mesmo lote ao longo da linha. Totalizaram 11 coletas em um ano de estudo. Os resultados mostraram que a pasteurização, único ponto crítico de controle do processo, foi insuficiente para garantir a qualidade microbiológica do leite de acordo com os padrões microbiológicos vigentes, porque o leite cru apresentava péssima qualidade. Durante a coagulação houve crescimento médio de 1,70 ciclos log na população de mesófilos aeróbios e um crescimento médio >3,0 ciclos log na população de coliformes fecais. Durante a salga houve crescimento médio de 0,73 ciclos log na população de 
mesófilos aeróbios e um crescimento médio de 0,37 ciclos log na população psicrotróficos aeróbios. Ao longo da linha, verificou-se que houve crescimentos da ordem de 11,77 ciclos log de coliformes totais e de >9,68 ciclos log de coliformes fecais do leite pasteurizado até o queijo após a salga. Em relação ao Staphylococcus coagulase positiva não foi detectado aumento expressivo de sua população. Os resultados encontrados indicam que o queijo Minas frescal do laticínio estudado antes de ser embalado já se apresentava impróprio para o consumo, devido às altas contagens de coliformes totais e fecais podendo vir a causar riscos aos consumidores e que o próprio processo de fabricação foi responsável pela alta contaminação, constituindo um problema de saúde pública. 


\section{EVALUATION OF BACTERIAL POPULATION IN A DAIRY PROCESSING LINE OF “MINAS FRESCAL” CHEESE}

Author: MILENA OLIVIERI LISITA

Adviser: Prof. Dr. ERNANI PORTO

\section{SUMMARY}

The evaluation of aerobic mesophilic, of total and fecal coliforms and Staphylococcus positive coagulase microorganisms population in a dairy processing line of "Minas frescal" cheese submitted to inspection of Federal Service was studied. Three processing steps were analysed individually: the pasteurisation through samples of raw and pasteurised milk; the coagulation through samples of pasteurised milk, cut and drained curd; and the salting through samples of cheeses before and after salting and brine itself. The aerobic psichrotrophic microorganim's count was made because salting was carried out under refrigeration. After, all the samples of a same allotment were collected. In one year 11 collections were taken and analysed. The results showed that the pasteurisation, the unique control critical point in the process, was not able to ensure the microbial quality of milk in agreement to the microbial standards, due to the bad quality of the raw milk. On curding the aerobic mesophilic population had an average growth of 1.70 cycles log and the fecal coliforms had an average growth of $>3.0$ cycles log. On salting the aerobic mesophilic microorganisms had an average growth of 0.73 cycles log as well the aerobic psichrotrophic population had an average growth of 0.37 cycles log. In the processing line, had an average growth of 11.77 cycles log on the 
population of total coliforms and $>9.68$ cycles log on the population of fecal coliforms from pasteurised milk until the cheese after salting. An expressive increase of the number of Staphylococcus positive coagulase was not detected. The results indicated that the manufactured "Minas frescal" cheese was improper for consumption even before packing because the high counting of total and fecal coliforms, being harmful to consumers and the processing was responsible for the high contamination, being a potential public health problem. 


\section{INTRODUÇÃO}

A elaboração de queijos constitui uma das mais importantes atividades das indústrias de laticínios, sobretudo no Brasil, onde um dos tipos de maior consumo é o Minas frescal. Isto se deve, em parte, ao maior rendimento obtido na elaboração deste queijo, ao processamento simples e breve, o que possibilita um retorno rápido do investimento e, consequentemente, custos menores aos consumidores (Behmer, 1991). A fabricação do queijo tipo Minas frescal é de grande interesse para a indústria de laticínios do país, uma vez que é produto de grande aceitação, caracteriza-se como queijo tipicamente brasileiro e pode ser encontrado em praticamente todo o país (Isepon \& Oliveira, 1995).

O parque industrial de indústrias de laticínios controlado pelo S.I.F. indica que o nosso universo industrial hoje consta com acima de 2.200 estabelecimentos, com uma taxa de crescimento anual de 5,1\% em volume de leite processado. No decorrer dos anos o quadro de pessoal do S.I.F. foi sendo reduzido gradativamente. A permanecer a atual situação, sua força de trabalho será limitada a poucas indústrias, deixando a maior parte sem a supervisão do órgão de inspeção sanitária (Gomes, 2002).

De acordo com a Associação Brasileira das Indústrias de Queijo (ABIQ), o Brasil produz 400 mil toneladas de queijo por ano, dentre as quais 240 mil são produzidas sob inspeção federal, estadual ou municipal. A maioria desta produção (95\%) é considerada de consumo popular, destacando-se os queijos prato, mussarela, parmesão, Minas etc. (Furtado et al., 2003).

Diversos surtos de doenças têm sido associados à ingestão de produtos lácteos em razão principalmente, da presença de Staphylococcus aureus, Escherichia coli e 
Bacillus cereus; também há relatos de surtos mais graves causados por Listeria monocytogenes e Salmonella sp (Costa et al., 2002).

Falhas ocorridas durante a ordenha e o processamento, aliadas a temperaturas inadequadas de conservação no comércio varejista, são fatores que têm contribuído para a comercialização dos produtos lácteos com características microbiológicas fora dos padrões regulamentares (Gomes \& Gallo, 1995).

Os problemas com a produção de queijos no Brasil estão relacionados com as precárias condições do leite produzido, as péssimas condições de fabricação dos queijos (em especial Minas frescal) e a falta ou ineficiência do sistema de refrigeração ao longo desta cadeia produtiva, que agravam a situação e criam condições de contaminação e desenvolvimento de microrganismos em diferentes pontos.

Pesquisas microbiológicas realizadas com queijo tipo Minas frescal têm permitido o isolamento de numerosos patógenos de importância em Saúde Pública. Dentre eles destacam-se o Staphylococcus aureus, o de maior ocorrência, secundado pelos coliformes fecais, diversos sorogrupos de Escherichia coli e Listeria monocytogenes (Pinto et al., 1996). Em agosto de 1990, na cidade de Belo Horizonte, um surto de intoxicação causada por queijo “tipo Minas”, contaminado com S. aureus produtor de enterotoxina B, envolveu 7 pessoas (Pereira et al., 1991). Carmo et al. (2002) descreveram surtos de intoxicações envolvendo 50 pessoas causados por cepas de Staphylococcus enterotoxigênicas, coagulase positivas, com produção das enterotoxinas A, B e C, que foram isoladas de queijo Minas Frescal.

Um estudo feito em Campinas com o queijo frescal revelou que das 210 amostras analisadas, 70 (33,33\%) ficaram fora de um ou de mais padrões microbiológicos estabelecidos pela legislação, sendo classificadas como produtos em condições sanitárias insatisfatórias, portanto, impróprios para o consumo. Eles tinham saído contaminados das fábricas e apresentaram o mesmo nível de contaminação no comércio varejista (Omairi, 2002).

Nascimento et al. (2001), em estudo sobre fatores de risco na contaminação natural de coliformes fecais em queijo Minas frescal, constataram que o registro S.I.F. 
não garantiu a qualidade higiênico-sanitária da maioria dos queijos. Fato semelhante foi constatado em Minas Gerais, onde 90\% dos queijos do tipo frescal com S.I.F. apresentaram elevado número de coliformes fecais (Pereira et al., 1999). 


\section{REVISÃO DE LITERATURA}

\subsection{O queijo Minas Frescal}

Começou-se a fazer queijo no Brasil a partir de 1536, com a chegada do primeiro rebanho de bovinos ao país. Faltam registros confiáveis, mas a informação mais segura que se dispõe refere-se ao início do século XIX, quando a região do Serro, em Minas Gerais, começou a produzir um queijo tipo caseiro, nos moldes do queijo serra-daestrela de Portugal (Empresa de Pesquisa Agropecuária de Minas Gerais - EPAMIG, 1987). Era conhecido como Queijo-de-Minas, que deu origem aos seguintes queijos: Minas frescal, Minas Curado ou Minas Padrão ou Prensado, queijo do Serro, queijo de Coalho, queijo Minas de Araxá, entre outros (Abreu, 1999).

Entretanto, a fabricação de queijos no Brasil, do ponto de vista industrial, é de história relativamente recente, sobretudo, a partir da década de 20 , com o estabelecimento de imigrantes dinamarqueses no sul de Minas e holandeses na região de Santos Dumont e Barbacena, também em Minas Gerais (Furtado, 1991).

A partir da década de 80, o volume de produção do queijo Minas frescal superou o do queijo Minas curado. O Minas frescal até então representava menos de 1/3 do total fabricado dentre as duas variedades (Santos, 2004). Em um levantamento feito em 2000, o queijo Minas frescal figurou entre os três queijos mais produzidos pela indústria nacional de laticínio, perdendo apenas para os queijos mussarela e prato, que representam 39,60\% e 29,57\%, respectivamente (Omairi, 2002).

É um produto de grande popularidade, aceitação, consumo e produção em quase todo o país. Sua massa é crua, com alto teor de umidade (46 - 55\%) e não maturada, que deve ser consumido nos primeiros quinze dias após sua fabricação, sendo, portanto, um 
produto altamente perecível (Hoffman et al., 2002). Elaborado a partir do leite bovino, sua principal característica é o sabor pouco ácido e rico. Queijos frescos, brancos e leves que são submetidos a um processamento mínimo antes de serem embalados são altamente perecíveis e por isso, apresentam vida útil curta, mesmo sob refrigeração (Silva et al., 2003).

Segundo a Portaria n 352 do Ministério da Agricultura e do Abastecimento (Brasil, 1997b), o queijo Minas frescal é um queijo fresco obtido por coagulação enzimática do leite com coalho e/ou outras enzimas coagulantes apropriadas, complementada ou não com ação de bactérias láticas específicas. É classificado como um queijo semigordo de alta umidade a ser consumido fresco, de consistência branda e macia, com ou sem olhaduras mecânicas, de cor esbranquiçada, de sabor suave a levemente ácido, sem ou com crosta fina, de forma cilíndrica e com peso de 0,3 a 5kg. O Ministério da Agricultura, em março de 2004, através da Instrução Normativa $n^{0} 4$ (Brasil, 2004 a) resolveu corrigir a classificação da umidade, considerando como queijo semigordo de muito alta umidade.

De acordo com os Padrões Microbiológicos vigentes, da Resolução Colegiada (RDC) $\mathrm{n}^{\circ} 12$ (Brasil, 2001) os queijos de muito alta umidade (>55\%), como o Minas Frescal elaborado por coagulação enzimática e sem a ação de bactérias láticas, deve apresentar as seguintes tolerâncias para amostras representativas: $5 \times 10^{2}$ UFC (Unidades Formadoras de Colônias) de coliformes de origem fecal/g, 5x10² UFC de estafilococos coagulase positiva/g, e ainda ausência de Salmonella sp e Listeria monocytogenes em 25g. De acordo com os requisitos da Portaria 146 (Brasil, 1996), as tolerâncias são de $1 \times 10^{3}$ UFC de coliformes totais/g, $5 \times 10^{2}$ UFC de coliformes de origem fecal/g, $5 \times 10^{2}$ UFC de estafilococos coagulase positiva/g, $5 \times 10^{3}$ UFC de fungos e leveduras/g e ausência de Salmonella sp e Listeria monocytogenes em 25g.

\subsubsection{Fabricação do queijo Minas frescal}

O processamento do queijo Minas frescal é semelhante ao do “Queso Blanco” de coagulação enzimática ou “Queso Fresco”, no entanto, atualmente, existem no comércio 
queijos produzidos por outros processos como a ultrafiltração e acidificação do leite pela adição de ácido lático em substituição da cultura lática (Kabuki, 2004).

O queijo Minas frescal é tradicionalmente produzido com adição de coalho, industrialmente é feito com leite pasteurizado, adicionado de fermento e de coalho (Fundação Centro Tecnológico de Minas Gerais - CETEC, 1985). Com a evolução das técnicas industriais, a tecnologia de fabricação do Minas frescal sofreu modificações visando ora a melhoria da qualidade do produto, ora um aumento no rendimento. Nesta evolução constante surgiram modificações diversas, entre elas a fabricação com leite pasteurizado, uso de cloreto de cálcio e emprego de culturas láticas (Furtado et al., 1980a).

A diversificação da metodologia para a elaboração de queijo Minas pode ser comprovada nas linhas de produção de diversas indústrias. Diferentes procedimentos de pasteurização do leite, de tratamento do coágulo, de salga, de embalagem e maturação vêm sendo adotados, trazendo como conseqüência, uma série de problemas, dentre os quais a dificuldade de implantação de um eficiente sistema de controle de qualidade, quer por parte da indústria, quer pelos órgãos de Inspeção (Santos, 1990).

Um dos maiores problemas apresentados por esse produto é sua pequena durabilidade no mercado que se deve essencialmente aos fenômenos de acidificação e proteólise, provocados pela ação das bactérias da cultura lática, respectivamente, sobre a lactose e proteínas do queijo. A alteração na tecnologia de fabricação com a utilização do ácido lático em substituição ao fermento lático teve como resultados principais o aumento na umidade e do $\mathrm{pH}$ do queijo, baixa acidez e maior perda de sólidos solúveis no soro (Furtado et al, 1980a). O emprego de ácido lático é o método que apresenta melhores vantagens do ponto de vista técnico e econômico, basicamente por ser de mais fácil aplicação e por proporcionar maior rendimento (Furtado et al., 1980b).

Porém, o uso de fermento lático na fabricação de Minas frescal pode constituir-se numa ferramenta importante para o controle do desenvolvimento da microbiota contaminante ao longo de sua comercialização. Suprimir o fermento pode significar a 
possibilidade de proliferação de eventuais microrganismos contaminantes, pela falta da atividade de antagonismo desempenhada pelas bactérias láticas do fermento (Lourenço Neto, 1999). Sua aplicação no início do processamento do queijo é uma das formas de aumentar a acidez rapidamente e de estabilizar e/ou diminuir a multiplicação de patogênicos (Alves et al., 2003).

Após a pasteurização o leite não possui uma microbiota dominante, portanto na elaboração dos queijos procede-se a adição de uma cultura lática. Com o seu desenvolvimento ocorre uma produção contínua e controlada de ácido lático, que dificulta o desenvolvimento de microrganismos indesejáveis, proporciona melhores condições para atuação do coalho e facilita a expulsão do soro (Bonassi et al., 1978).

Dentre as várias maneiras de se proceder a salga dos queijos, destaca-se a imersão do produto em salmoura, cujo período de tempo varia em função do tipo de queijo (Behmer, 1991). No caso específico do queijo Minas Frescal a salga é feita a 10$12^{\circ} \mathrm{C}$ em salmoura com $20 \%$ de sal, por períodos proporcionais ao peso e formato do queijo (exemplo: queijos de 0,5 kg: 90 minutos; e 1,0 kg: 3 - 4 horas). Este método é bastante usado; os queijos são colocados na salmoura após aproximadamente 12-18 horas após serem enformados (Campos \& Prado Filho, 2001).

A qualidade microbiológica das salmouras é de fundamental importância, porque ela pode constituir-se em fonte de contaminação para os queijos. Especial atenção deve ser dispensada às características microbiológicas da água e do sal utilizados no preparo das salmouras (Amaral et al., 1991). A este respeito, os mesmos autores, estudando as características microbiológicas das salmouras utilizadas na salga de queijos Minas frescal, observaram elevados índices de contaminação, cujas contagens de microrganismos mesófilos, coliformes totais, coliformes de origem fecal, Staphylococcus aureus, e de bolores e leveduras atingiram valores respectivos da ordem de $2,9 \times 10^{11}, 7,8 \times 10^{12}, 7,8 \times 10^{12}, 2,3 \times 10^{3}$ e $7,4 \times 10^{5} \mathrm{UFC} / \mathrm{mL}$. 


\subsubsection{O leite como matéria-prima}

No Brasil, a qualidade higiênica insatisfatória do leite produzido é um problema crônico, de difícil solução, porque fatores de ordem social, econômica e cultural estão envolvidos e não têm recebido a devida atenção no campo político, apesar do importante papel representado pelo leite na alimentação da população (Silveira et al., 1998). Cerca de $48 \%$ da produção leiteira brasileira é realizada de forma clandestina, ou seja, à margem de qualquer tipo de fiscalização efetiva por parte das autoridades competentes (Almeida Filho et al., 2002).

A qualidade do leite cru está associada à carga microbiana presente e a microbiota inicial terá uma influência direta na qualidade do leite pasteurizado, assim como nos produtos lácteos (Mutukumira et al., 1996). O leite destinado ao fabrico de queijos deve ser de boa qualidade e, quanto possível, livre de contaminação bacteriana ou por agentes químicos como antibióticos, herbicidas, pesticidas, etc (Perry, 2004).

Conforme Rapini et al. (2003) a carga microbiana inicial do leite está diretamente relacionada à higiene e ordenha e à limpeza dos utensílios utilizados para sua coleta e transporte. Dentre as bactérias passíveis de serem encontradas no leite, pode-se destacar o Staphylococcus aureus, pois vários fatores propiciam condições favoráveis à sua contaminação, entre os quais a prevalência do microrganismo como agente etiológico da mastite bovina (Gomes \& Gallo, 1995). A mastite por Staphylococcus associada a condições higiênico-sanitárias em laticínios e transporte de leite sem refrigeração é considerada responsável pela alta incidência desse gênero de microrganismo em leite cru (Pereira et al., 1991).

O leite recém-ordenhado, em condições de assepsia, contém entre $5 \times 10^{3}$ a $5 \times 10^{4}$ UFC/mL, constituídos de contaminantes procedentes dos galactóforos, equipamentos de ordenha e manipuladores, de modo que deve ser resfriado tão rapidamente quanto possível para manter sua qualidade bacteriológica (Hayes, 1993). Porém, do ponto de vista de Prata (1998), contagens de microrganismos de $<10^{6} \mathrm{UFC} / \mathrm{mL}$ não causam 
alterações significativas no leite, mas o crescimento bacteriano é sempre prejudicial, seja pelas modificações que possam acarretar pelo possível desenvolvimento de patogênicos e ou pela produção e acúmulo de toxinas.

Recomendações são feitas para a produção segura de queijos e geralmente indicam a necessidade de utilizar leite pasteurizado para minimizar riscos à saúde pública. Além desta, outras medidas são importantes para assegurar a produção de queijos livres de patógenos, tais como: o leite cru deve ser coletado e mantido sob boas condições de higiene, deve ser refrigerado para minimizar a multiplicação de microrganismos, se não for utilizado imediatamente, deve sofrer pasteurização completa ou processo equivalente e ser mantido em boas condições de higiene desde a fabricação até a venda dos queijos aos consumidores, impedindo a contaminação (Leite, 2000).

\subsection{Microrganismos mesófilos aeróbios}

A contagem total de microrganismos mesófilos aeróbios é usada como indicadora da população bacteriana em uma amostra. É uma contagem genérica para microrganismos que crescem aerobiamente em temperaturas de incubação entre 15 e $45^{\circ}$ C, com uma temperatura média de $35^{\circ} \mathrm{C}$ (Carvalho, 2001; Morton, 2001). Membros esporulados deste grupo de significância em alimentos pertencem aos gêneros Bacillus e Sporolactobacillus (Vanderzant \& Splittstoesser, 1992).

É um dos indicadores microbiológicos de qualidade mais comumente utilizado, mas não é aplicável aos alimentos em que há processo de fermentação. Indica se a limpeza, a desinfecção e o controle da temperatura durante os processos de tratamento industrial, transporte e armazenamento foram realizados de forma adequada (International Comission on Microbiological Specifications for Foods - ICMSF, 1982). Pode transmitir informação ao processador de alimentos a respeito da vida útil ou tendência a mudanças organolépticas (Morton, 2001).

A contagem elevada deste grupo de bactérias nos alimentos perecíveis também é indicativo do uso de matéria-prima contaminada ou processamento insatisfatório, sob o ponto de vista sanitário (Franco \& Landgraf, 1996). E, como a maioria das bactérias 
patogênicas é mesófila, uma alta contagem seria indicativo de maior possibilidade de ocorrência de bactérias patogênicas (Carvalho, 1999).

\subsection{Microrganismos psicrotróficos aeróbios}

Microrganismos psicrotróficos podem ser definidos como os que apresentam crescimento visível a $7^{\circ} \mathrm{C} \pm 1^{\circ} \mathrm{C}$ no período de sete a dez dias, independentemente de sua temperatura ótima de crescimento. É um grupo importantíssimo em produtos que são conservados sob refrigeração por períodos entre 1 e 4 semanas (Perry, 2004).

Bactérias psicrotróficas são, em sua maioria, Gram negativas e são encontradas em ambientes onde temperaturas estão constantemente entre $15^{\circ}$ e $20^{\circ} \mathrm{C}$ (Cousin et al., 2001). O comportamento em baixas temperaturas varia conforme a bactéria envolvida. As bactérias Gram positivas são mais resistentes ao frio que as Gram negativas, como Escherichia coli, Pseudomonas, Alcaligenes, Salmonella e Vibrio. A destruição ou injúria é maior entre $-2^{\circ} \mathrm{C}$ e $-10^{\circ} \mathrm{C}$, quando comparada com temperaturas mais baixas, como $-15^{\circ} \mathrm{C}$ e $-30^{\circ} \mathrm{C}$ (Franco \& Landgraf, 1996).

A presença de grande número de espécies de microrganismos psicrotróficos pode estar relacionada com ocorrência de toxinfecções alimentares humanas ou com deterioração e perda da qualidade organoléptica dos alimentos (Santos et al., 1999).

A introdução da armazenagem refrigerada no leite cru antes de seu processamento, sanou os problemas de alterações de sabor e desenvolvimento de acidez neste produto devido à ação das bactérias mesofílas, mas trouxe à tona outro sério problema: a seleção de microrganismos psicrotróficos (Furtado, 1999).

Os principais gêneros bacterianos envolvidos na alteração do leite e seus derivados são as bactérias do gênero Pseudomonas spp. e as do gênero Bacillus spp, por apresentarem cepas psicrotróficas e produtoras de enzimas termorresistentes,. Espécies de psicrotróficos potencialmente patogênicos (Yersinia enterocolitica, Listeria monocytogenes e Bacillus cereus) também podem estar presentes nos produtos citados e, em relação à quantidade, as alterações de natureza proteolítica e/ou lipolítica aparecem quando a contagem destes microrganismos atinge $10^{7} \mathrm{UFC} / \mathrm{g}$ (Santos et al., 1999). 


\subsection{Staphylococcus}

O gênero Staphylococcus, pertencente à família Microccocaceae, é composto por cocos Gram positivos, imóveis, mesófilos, não esporulados e agrupados irregularmente em forma de cachos. Catalase positivos, possuidores de metabolismo respiratório e fermentativo, são anaeróbios facultativos (Sneath, 1986). Atualmente o gênero comporta um total de 33 espécies (Downes \& Ito, 2001). Dentro destas, Staphylococcus aureus pode ser diferenciado por coagular plasma, produzir Dnase termoestável e fermentar o manitol (Sneath, 1986; ICMSF, 1996).

A produção de coagulase com indicação de patogenicidade do $S$. aureus é amplamente difundida (Vanderzant \& Splittstoesser, 1992; Food and Drug Administration - FDA, 1995). Cepas coagulase-negativas produtoras de enterotoxinas têm sido isoladas, mas há pouca informação sobre seu papel na intoxicação alimentar (Carmo et al., 2002).

S. aureus é mau competidor e, por isso, raramente causa intoxicação em alimentos in natura, com exceção do leite proveniente de vaca com mastite, em que su população pode ser bem elevada. São destruídas pelas temperaturas de cocção, mas as toxinas produzidas não. O microrganismo tolera altas concentrações de sal (25\%), é resistente a processos de secagem e pode crescer e produzir enterotoxinas em produtos que tenham atividade de água tão baixa quanto 0,85 (ICMSF, 1996). Cepas proteolíticas têm crescimento mínimo em temperaturas entre $5^{\circ}$ e $15^{\circ} \mathrm{C}$ (Vanderzant \& Splittstoesser, 1992).

De acordo com Baird-Parker (1990) são duas as categorias de patologias produzidas pelo S. aureus: a) Quadros infecciosos provocados pela ação direta do microrganismo, podendo ser localizados ou septicêmicos; b) Quadros toxêmicos provocados pela ação de suas toxinas, como síndrome tóxica e intoxicação alimentar. Esta última é de grande interesse na indústria alimentar. 
Tabela 1 - Limites para o crescimento e produção de enterotoxina do S. aureus.

\begin{tabular}{lcccc}
\hline \multirow{2}{*}{ Fator } & \multicolumn{2}{c}{ Crescimento } & \multicolumn{2}{c}{ Produção de enterotoxina } \\
\cline { 2 - 5 } & Ótimo & Limite & Ótimo & Limite \\
\hline Temperatura $\left({ }^{\circ} \mathrm{C}\right)$ & 37 & $7-48$ & $40-45$ & $10-48$ \\
$\mathrm{pH}$ & $6-7$ & $4-10$ & $7-8$ & $4,5-9,6^{*}$ \\
$\mathrm{Aw}$ & 0,98 & $0,83->0,99^{*}$ & 0,98 & $0,87->0,99^{*}$ \\
\hline
\end{tabular}

* Somente aeróbio

Fonte: Adaptação de ICMSF (1996).

A intoxicação por diferentes linhagens de Staphylococcus (enterotoxicose) pode ser ocasionada pela ingestão de uma ou mais das enterotoxinas termoestáveis A, B, C, D, E ou F (Fueyo et al., 2001). O período de incubação pode variar de 1 a 7 horas, sendo geralmente de 2 a 4h após ingestão do alimento. Os sintomas mais comuns são: repentino mal-estar com náuseas, salivação intensa, vômito, convulsões, diarréia, dores abdominais, desidratação, suores, fraqueza, prostração, mas normalmente não se observa febre. Em alguns casos pode ocorrer dor de cabeça e a recuperação se dá, normalmente, em dois dias (ICMSF, 1996).

A primeira associação a intoxicação alimentar estafilocóccica provavelmente foi feita em 1884, quando descreveram um surto em Michigan que acreditavam ter sido causado por consumo de queijo. Trinta anos mais tarde demonstrou-se claramente a intoxicação alimentar estafilocóccica pelo consumo de leite guardado sem refrigeração, procedente de vaca com mastite (Carvalho, 2001).

Santos \& Genigeorgis (1981) estudaram a capacidade de S. aureus sobreviver, crescer e produzir enterotoxina no queijo Minas. Nesse estudo, populações de $S$. aureus maiores que $10^{6} \mathrm{UFC} / \mathrm{g}$ foram observadas em 57,44\% (27 de 47) dos queijos feitos com leite pasteurizado e as enterotoxinas A, B e C foram detectadas em 62,5\% (10 de 16). Mandil et al. (1982) e Delazari et al. (1978) comprovaram a produção de enterotoxina A quando a população de $S$. aureus atingia contagens de $10^{5}$ /g em queijo tipo “Minas”. 
Tabela 2 - Relatos de toxinfecções alimentares causadas pela ingestão da enterotoxina estafilocóccica (Minas Gerais de 1995 a 2001).

\begin{tabular}{lccc}
\hline Alimento contaminado & Surtos & Pessoas intoxicadas & Óbitos \\
\hline Queijos (diversos) & 23 & 660 & 01 \\
Bolo recheado & 20 & 750 & - \\
Refeição pronta & 52 & 9.500 & $16^{*}$ \\
Frango e embutidos & 05 & 600 & - \\
Leite e derivados & 06 & 380 & - \\
Massas & 03 & 130 & - \\
Maionese caseira & 03 & 800 & - \\
Total & 112 & 12.820 & 17 \\
\hline
\end{tabular}

* 16 ocorridos em um surto durante uma festa de confraternização

Fonte: Carmo (2001).

Wendpap \& Rosa (1993), estudando o queijo Minas consumido no município de Cuiabá - MT, detectaram Staphylococcus aureus em 40\% das amostras analisadas apresentando população acima de $10^{5} \mathrm{UFC} / \mathrm{g}$. Hoffman et al. (2002), analisando 10 amostras de queijos tipo "Minas Frescal" comercializados em feiras livres na região de São José do Rio Preto - SP, verificaram que todas estavam fora dos padrões microbiológicos vigentes para Staphylococcus aureus. Gomes \& Gallo (1995), encontraram contagens desse microrganismo variando de $4,7 \times 10^{4}$ a 1,4 x $10^{6} \mathrm{UFC} / \mathrm{g}$ em queijos Minas frescal comercializados em Piracicaba.

\subsection{Coliformes totais e fecais}

A utilização de certos microrganismos do grupo coli-aerogenes como indicação de contaminação de origem fecal da água e dos alimentos é uma prática estabelecida há muitos anos. A partir de 1920 se introduziu a utilização do grupo coliforme como indicadores em análises microbiológicas de leite pasteurizado e dos sorvetes, baseando no princípio de que um tratamento térmico adequado eliminaria todas as bactérias 
presentes neste grupo e de que a embalagem deveria impedir a recontaminação do produto (Mossel \& Garcia, 1988).

O grupo dos coliformes totais inclui as bactérias na forma de bastonetes Gram negativos, não esporogênicos, aeróbios ou anaeróbios facultativos, capazes de fermentar a lactose com produção de gás, em 24 a 48 horas a $35^{\circ} \mathrm{C}$. A definição dos coliformes fecais é a mesma, porém, restringindo-se aos membros capazes de fermentar a lactose com produção de gás, em 24 h a 44,5 - 45,5º (Silva et al., 1997).

O grupo coliforme fecal é restrito aos organismos que vivem exclusivamente no trato gastrintestinal de humanos e de animais de sangue quente. Isto inclui pelo menos três gêneros: Escherichia, Klebsiella e Enterobacter (Hitchins et al., 1992; Silva et al., 1997). Dentre essas bactérias, a $E$. coli é a mais conhecida e a mais facilmente diferenciada dos microrganismos não fecais. Todos os demais pertencentes ao grupo têm uma associação duvidosa com a contaminação fecal e E. coli, embora possa ser introduzida nos alimentos a partir de fontes não fecais, é o melhor indicador de contaminação fecal conhecido até o momento (Silva et al., 1997).

Diversas linhagens de E. coli são comprovadamente patogênicas para o homem e para os animais. Com base nos fatores de virulência, manifestações clínicas e epidemiologia, as linhagens de E. coli consideradas patogênicas são, atualmente, agrupadas em cinco classes: EPEC (E. coli enteropatogênica clássica); EIEC (E. coli enteroinvasora); ETEC (E. coli enterotoxigênica); EHEC (E. coli entero-hemorrágica); e, EAggEC (E. coli enteroagregativa) (Franco \& Landgraf, 1996).

Recentemente algumas cepas de E. coli têm sido relacionadas com graves surtos de toxinfecção alimentar em vários países. Cepas como a O157:H7 (cepa enterohemorrágica) tem causado graves transtornos em todo o mundo, inclusive com muitos casos fatais (Almeida Filho et al., 2002). 
Tabela 3 - Gêneros detectados e não detectados nas provas para coliformes.

\begin{tabular}{lccc}
\hline Gênero & $\begin{array}{c}\text { Predominantemente de } \\
\text { origem fecal }\end{array}$ & $\begin{array}{c}\text { Geralmente } \\
\text { detectado }\end{array}$ & $\begin{array}{c}\text { Tipicamente enteropatogênico } \\
\text { para o homem }\end{array}$ \\
\hline Escherichia & Sim & Sim & Não \\
Edwarsiella & Sim & Não & Não \\
Citrobacter & Não & Sim & Não \\
Salmonella & Sim & Não & Sim \\
Shigella & Sim & Não & Sim \\
Klebsiella & Não & Sim & Não \\
Enterobacter & Não & Sim & Não \\
Hafnia & Não & Não & Não \\
Serratia & Não & Não & Não \\
Proteus & Não & Não & Não \\
Yersinia & Sim & Não & Não \\
Erwinia & Não & Não & Não \\
\hline
\end{tabular}

Fonte: Figueiredo (1999).

A E. coli também pode produzir mastite. Apesar de não se ter comprovado a relação direta entre a mastite por E. coli e enfermidade humana, foi isolada uma ampla variedade de sorotipos de $E$. coli a partir do leite da vaca e é provável que alguns destes sejam patógenos para o homem (Carvalho, 2001).

Oliveira et al. (1998) analisando 32 amostras de queijos Minas frescal de seis fábricas de laticínios localizadas na região nordeste do Estado de São Paulo, totalizaram três amostras $(9,4 \%)$ com populações de coliformes fecais acima do limite estabelecido pelas legislações. Também fora dos padrões, Almeida Filho \& Nader Filho (2002), encontraram 37,5\% (30 de 80) das amostras de queijos Minas frescal comercializados em Poços de Caldas - MG.

Leite (2000), avaliando amostras de queijos Minas frescal elaborados em três indústrias de laticínios no município de Lavras - MG, detectou uma população de $10^{6} \mathrm{NMP}$ de coliformes fecais/g. Almeida Filho et al. (2002)

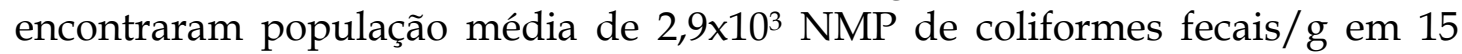
amostras de queijo Minas frescal submetidos à inspeção federal, comercializados em Cuiabá - MT. 


\section{MATERIAL E MÉTODOS}

Esse trabalho foi realizado no laboratório de Laticínios do Departamento de Agroindústria, Alimentos e Nutrição da Escola Superior de Agricultura "Luiz de Queiroz” da Universidade de São Paulo. Todas as amostras foram coletadas de uma fábrica de laticínios do Estado de São Paulo sujeita à inspeção do S.I.F.

\subsection{Descrição do processamento}

O laticínio, por ser um entreposto de recebimento de leite para processamento de ultra alta temperatura (UAT, em inglês UHT), recebe diariamente cerca de 12 mil litros de leite de aproximadamente 100 diferentes produtores. São utilizados para a fabricação do queijo Minas frescal, em média, 4 mil litros por mês. A rotina de produção do Minas frescal envolve:

a) Recepção do leite.

O leite é recepcionado em plataforma a partir das 7 horas da manhã. Chega em recipientes de plástico com capacidade de $50 \mathrm{~L}$ e são transportados, a maioria em caminhões e alguns em veículos utilitários ou de tração animal, sem refrigeração. Imediatamente antes de ser despejado no tanque de recepção é feito o teste do alizarol em amostras de cada latão. As análises de densidade, crioscopia, acidez titulável e medição de temperatura são realizadas por amostragem de produtores, em média de $20 \%$ deles. A temperatura do leite cru no tanque varia de 14 a $18{ }^{\circ} \mathrm{C}$. Os recipientes, vazios, são lavados em máquinas apenas com água quente e vapor. 
b) Pasteurização do leite.

É realizada a pasteurização rápida, em trocador de calor de placas, a $74^{\circ} \mathrm{C}$ por 15 segundos sob uma vazão de $5000 \mathrm{~L} / \mathrm{h}$. Antes de se proceder a pasteurização, é passada água quente a $85^{\circ} \mathrm{C}$ é durante $1 \mathrm{~h}$ pelo equipamento. A limpeza do pasteurizador é feita ao final do expediente utilizando solução com 10\% de soda cáustica por 1h30min a $85^{\circ} \mathrm{C}$, e depois solução com $5 \%$ de ácido nítrico por $1 \mathrm{~h}$ a $50^{\circ} \mathrm{C}$.
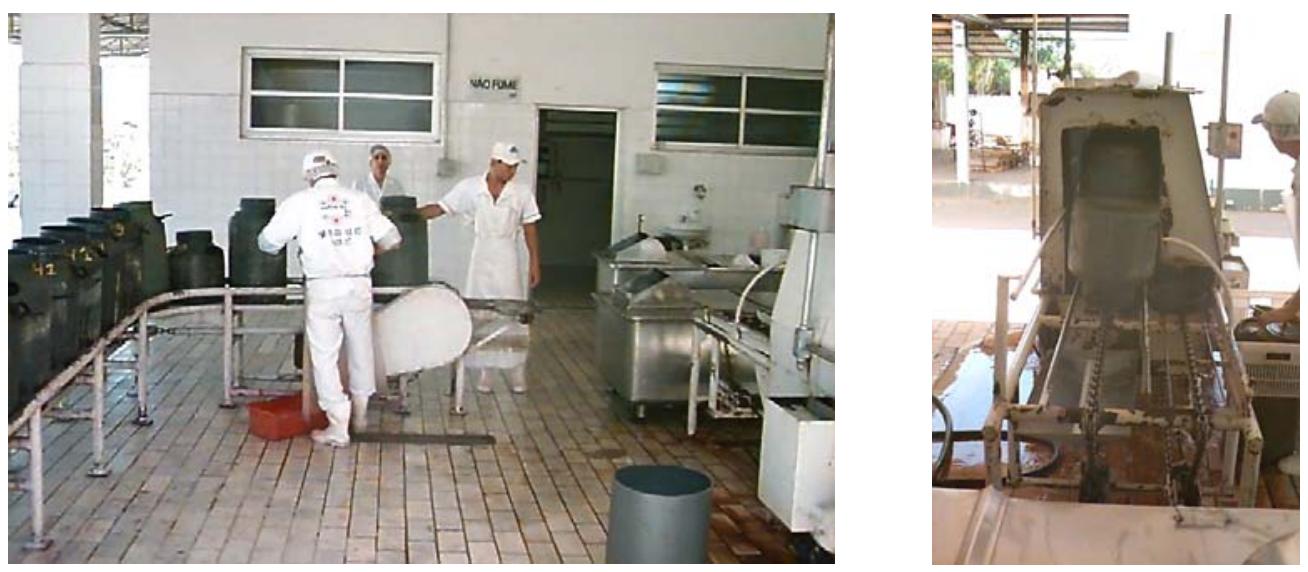

Figura 1 - Plataforma de recepção do leite e máquina de lavar os recipientes.

c) Coagulação e enformagem.

O leite sai do pasteurizador e por uma tubulação de encaixe é diretamente despejado no tanque de coagulação à uma temperatura aproximada de $35^{\circ} \mathrm{C}$. O tanque, com capacidade de $2000 \mathrm{~L}$, é encamisado. Espera-se o leite atingir $42^{\circ} \mathrm{C}$ e para cada $1000 \mathrm{~L}$ de leite é feita a adição de 250 a $300 \mathrm{~mL}$ de cloreto de cálcio, seguida da adição da mesma proporção de ácido lático, e de 200 a $250 \mathrm{~mL}$ de coalho bovino. Homogeneiza-se por $1 \mathrm{~min}$ e espera-se coagular por 30 a $40 \mathrm{~min}$.

Espuma formada na superfície é retirada utilizando-se formas de enformagem e é atirada ao chão, conforme mostra Figura 2. A coalhada é cortada manualmente com liras e, após o corte, é realizada mexedura que leva de 30 a 40 min. Há um breve descanso antes da dessoragem, que é feita empurrando-se a massa para um canto do tanque com placas de polietileno, outra placa de metal é submersa e latões cheios de soro servem 
como peso, conforme mostra Figura 3. O soro é retirado por tubulação que é encaixada ao tanque e é bombeado para outro, como também é mostrado na Figura 3.

A massa é enformada, em formas de plástico com capacidade para 500 g ou $3 \mathrm{~kg}$ com auxílio de faca, conforme é mostrada na Figura 4. É feita uma única viragem após 30 - 40 min. Todo processo tem a duração de aproximadamente 3 h.

A liras, as placas e os latões ficam submersos em um tanque com solução clorada por 20 min e as formas ficam submersas por 2 min antes da utilização.
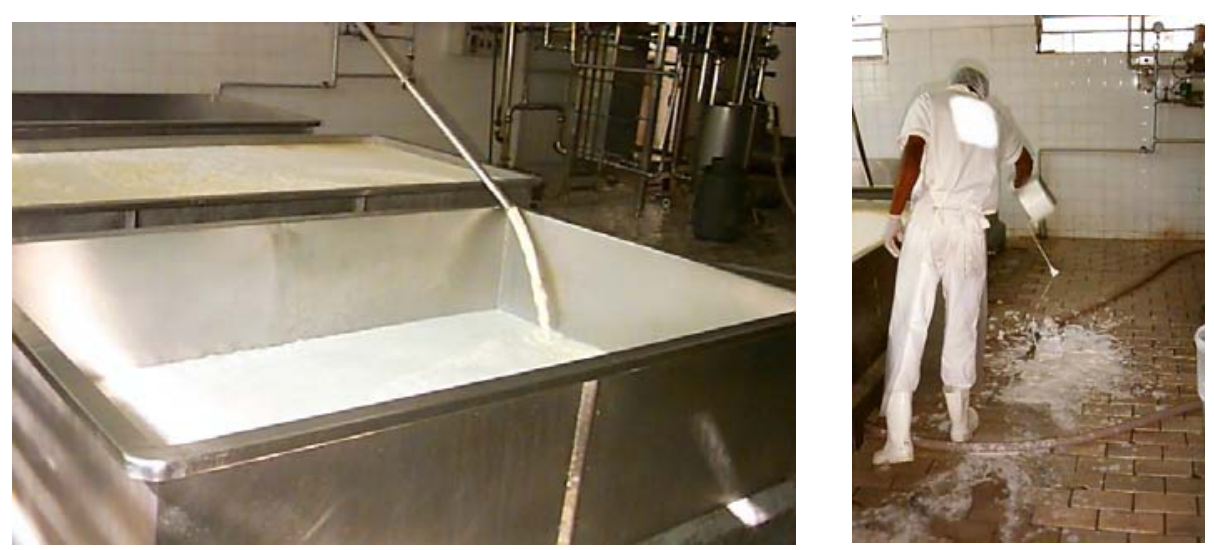

Figura 2 - Enchimento do tanque de coagulação com o leite saindo do pasteurizador. Espuma, que é formada na superfície da coalhada, sendo jogada no chão.
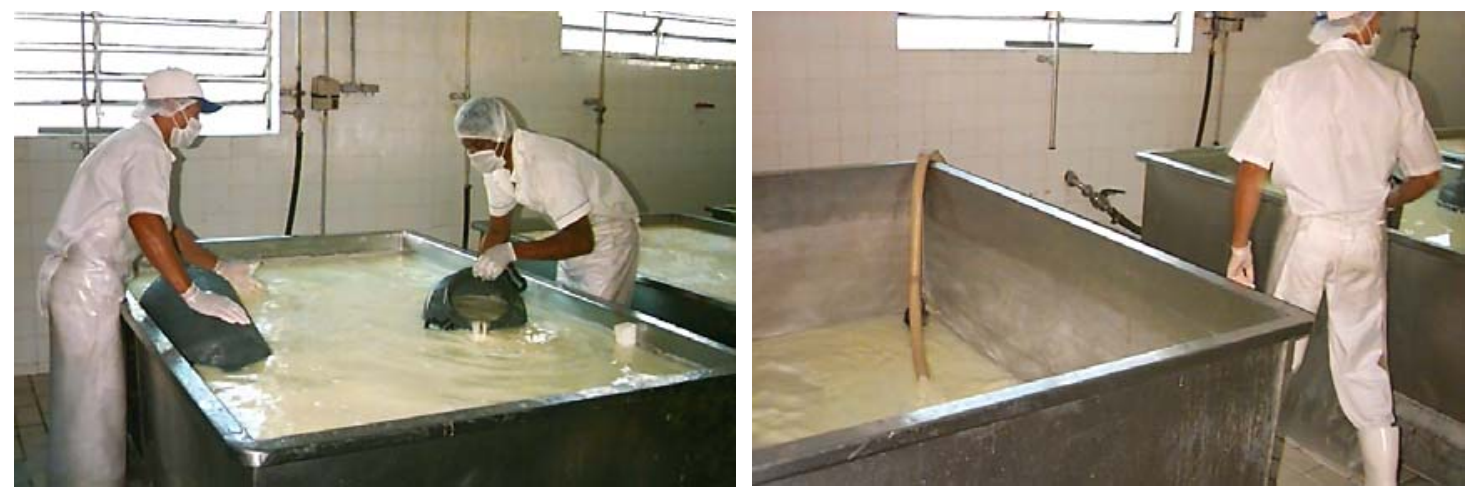

Figura 3 - Início da dessoragem. Soro sendo bombeado a outro tanque.

d) Refrigeração e salga

As formas com as massas são levadas em caixas para uma câmara de refrigeração a $9^{\circ} \mathrm{C}$ onde ficam até a manhã do dia seguinte, período de 20 h. Os queijos 
são retirados das formas e mergulhados em salmoura $(20 \% \mathrm{~m} / \mathrm{v})$ em um tanque de $800 \mathrm{~L}$ de capacidade que se encontra dentro da câmara, na qual permanecem por de 30 a 35 $\min$.

De acordo com o queijeiro da indústria, é feita a troca de água da salmoura em média 2 vezes ao ano. A cada dois meses a salmoura é bombeada juntamente com a salmoura da mussarela a outro tanque para aquecimento até ebulição e adição de mais $6,7 \% \mathrm{~m} / \mathrm{v}$ de sal grosso. Semanalmente é adicionado à salmoura $500 \mathrm{~mL}$ de solução peróxido de hidrogênio (130 volumes).
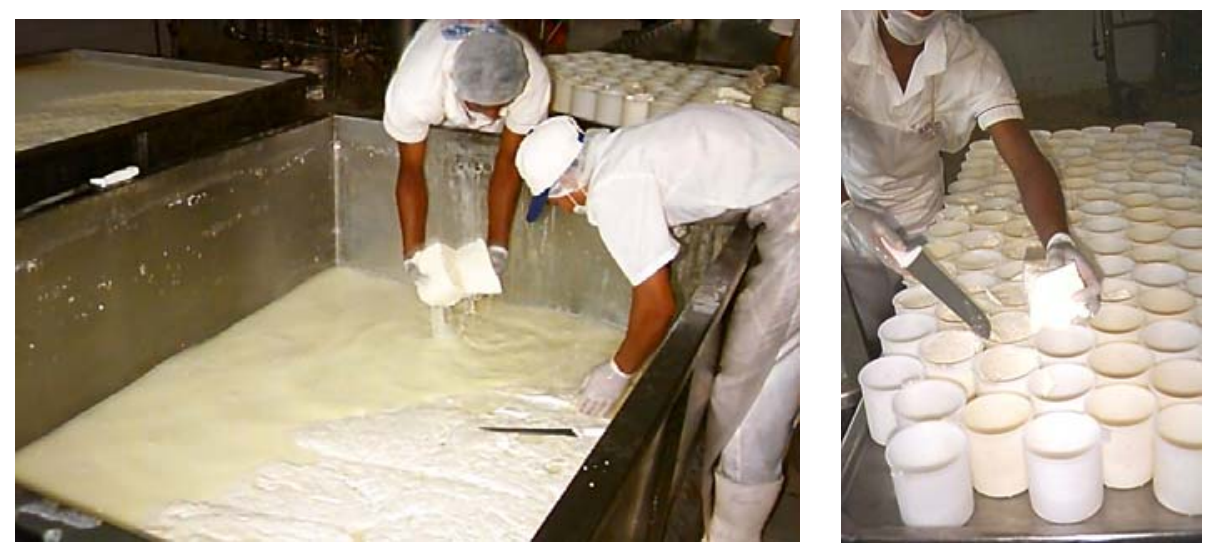

Figura 4 - Enformagem.

e) Embalagem

Os queijos salgados são levados em mesas de aço inox para serem embalados em embalagem plástica e fechados com fecho metálico. A data de fabricação é carimbada na embalagem, na qual é descrita a validade de 30 dias. São posteriormente armazenados em outra câmara frigorífica para distribuição. 


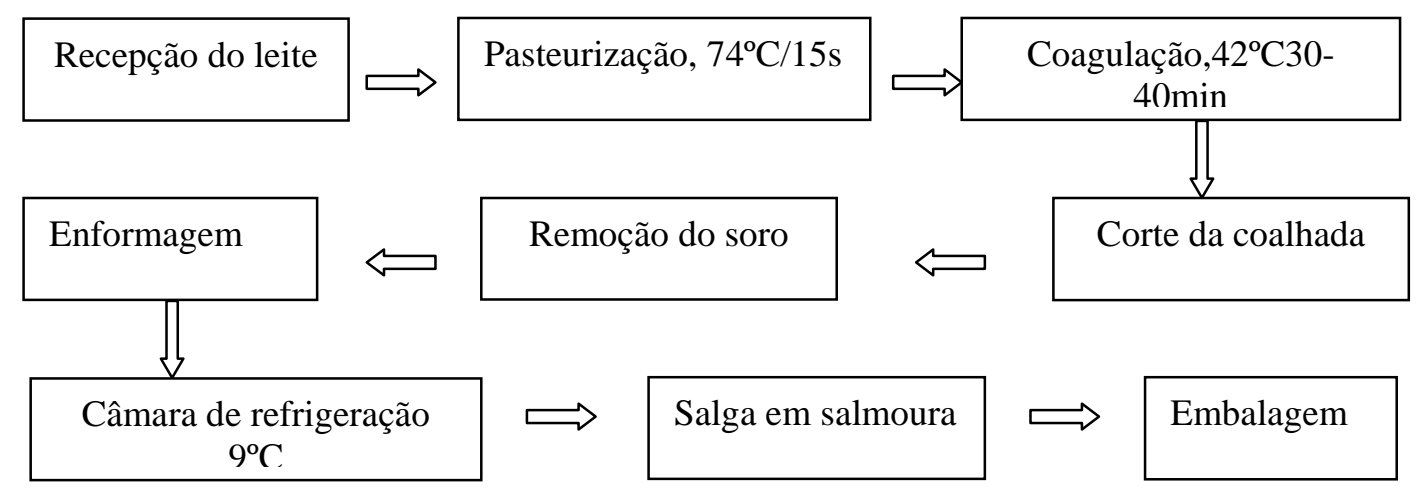

Figura 5 - Fluxograma de produção do queijo Minas Frescal.

\subsection{Amostragem}

Durante o período de março a novembro de 2004 e março de 2005, foram amostrados diversos produtos ao longo da linha de produção do queijo Minas frescal. Amostras de leite cru, leite pasteurizado, coalhada cortada, coalhada dessorada, queijo antes da salga, salmoura e queijo após a salga foram coletadas e acondicionadas em caixa de isopor com gelo para serem levadas ao laboratório, de acordo com Silva et al. (1997) e submetidas às análises. O tempo entre a amostragem e as análises não ultrapassou quatro horas.

Foram quatro coletas na pasteurização de amostras de leite cru e leite pasteurizado, numeradas de 1 a 4. Quatro coletas no tanque de coagulação de amostras de leite pasteurizado, coalhada cortada e coalhada dessorada, numeradas de 4 a 7 . Na quarta coleta foram tomadas amostras da pasteurização e do tanque de coagulação. Três coletas na salga, numeradas de 8 a 10, de amostras de salmoura, queijo antes da salga e queijo após a salga. Na última coleta, de $\mathrm{n}^{0} 11$, foram tomadas todas as diferentes amostras reunidas em um mesmo lote. Totalizaram, portanto, onze coletas, efetuadas em onze dias no período referido.

Todos os recipientes e utensílios utilizados nas coletas foram previamente esterilizados em autoclave a $121^{\circ} \mathrm{C}$ por $15 \mathrm{~min}$. Todas as operações de retirada de 
amostras para diluição foram efetuadas dentro de sala fechada, próximas a chama de meia altura de um bico de Bunsen.

Tabela 4 - Esquematização da amostragem.

\begin{tabular}{cccccccc}
\hline$\frac{\pi}{ \pm}$ & $\begin{array}{c}\text { Leite } \\
\text { cru }\end{array}$ & $\begin{array}{c}\text { Leite } \\
\text { pasteurizado }\end{array}$ & $\begin{array}{c}\text { Coalhada } \\
\text { cortada }\end{array}$ & $\begin{array}{c}\text { Coalhada } \\
\text { dessorada }\end{array}$ & $\begin{array}{c}\text { Queijo } \\
\text { antes salga }\end{array}$ & $\begin{array}{c}\text { Queijo } \\
\text { pós salga }\end{array}$ & Salmoura \\
\hline 1 & $\mathrm{X}$ & $\mathrm{X}$ & & & & & \\
2 & $\mathrm{X}$ & $\mathrm{X}$ & & & & & \\
3 & $\mathrm{X}$ & $\mathrm{X}$ & & & & & \\
4 & $\mathrm{X}$ & $\mathrm{X}$ & $\mathrm{X}$ & $\mathrm{X}$ & & & \\
5 & & $\mathrm{X}$ & $\mathrm{X}$ & $\mathrm{X}$ & & & \\
6 & & $\mathrm{X}$ & $\mathrm{X}$ & $\mathrm{X}$ & & & \\
7 & & $\mathrm{X}$ & $\mathrm{X}$ & $\mathrm{X}$ & & & \\
8 & & & & & $\mathrm{X}$ & $\mathrm{X}$ & $\mathrm{X}$ \\
9 & & & & & $\mathrm{X}$ & $\mathrm{X}$ & $\mathrm{X}$ \\
10 & & & $\mathrm{X}$ & & $\mathrm{X}$ & $\mathrm{X}$ & $\mathrm{X}$ \\
11 & $\mathrm{X}$ & $\mathrm{X}$ & $\mathrm{X}$ & $\mathrm{X}$ & $\mathrm{X}$ & $\mathrm{X}$ & $\mathrm{X}$ \\
\hline
\end{tabular}

\subsubsection{Amostras de leites cru e pasteurizado}

Amostras de aproximadamente $1 \mathrm{~L}$ de leite cru foram retiradas do tanque de recepção na plataforma de recepção com uma concha de metal esterilizada. Amostras de aproximadamente $1 \mathrm{~L}$ de leite pasteurizado foram assepticamente coletadas na saída da tubulação do pasteurizador. Todas foram colocadas em frascos de vidro esterilizados com capacidade de $1 \mathrm{~L}$.

Preparo das amostras de leites cru e pasteurizado:

Em tubos de diluição foram feitas diluições de $10 \mathrm{~mL}$ de leite em $90 \mathrm{~mL}\left(10^{-1}\right)$ de diluente, água peptonada 0,1\% estéril e, a partir destas retirou-se $1 \mathrm{~mL}$ para diluição em $9 \mathrm{~mL}$ de água peptonada e daí para sucessivas diluições decimais, conforme Downes \& Ito (2001). Com o leite cru, foram efetuadas diluições até $10^{-8}$ na $1^{\text {a }}$ coleta e $10^{-9}$ nas $2^{\mathrm{a}}$, 
$3^{\mathrm{a}}, 4^{\mathrm{a}}$ e $11^{\mathrm{a}}$. Com o leite pasteurizado, foram efetuadas diluições até $10^{-6}$ nas $1^{\mathrm{a}}, 2^{\mathrm{a}}, 3^{\mathrm{a}}, 4^{\mathrm{a}}$ e $11^{\mathrm{a}}$ coletas, $10^{-5}$ na $5^{\mathrm{a}}$ e $10^{-4}$ nas $6^{\mathrm{a}}$ e $7^{\mathrm{a}}$.

\subsubsection{Amostras de coalhadas e queijos}

Amostras de aproximadamente $1 \mathrm{~kg}$ de coalhada cortada e de $1 \mathrm{~kg}$ coalhada dessorada foram assepticamente coletadas do tanque de coagulação, com escumadeiras de alumínio esterilizadas e colocadas em frascos de vidro esterilizados. Denominou-se de coalhada cortada o produto imediatamente após o corte da coalhada e da qual foram tomadas amostras de diversas partes do tanque, no meio e nas laterais. Denominou-se de coalhada dessorada o produto imediatamente após a dessora, antes de ser enformado. Amostras de queijos antes e após a salga foram coletadas, de forma aleatória, tomandoas com escumadeiras de alumínio esterilizadas. Em cada amostragem foram tomados dois queijos de aproximadamente $0,5 \mathrm{~kg}$ cada, e colocados em béqueres de plástico esterilizados fechados com folha de alumínio.

Preparo das amostras de coalhadas e queijos:

Foram homogeneizados em liquidificadores previamente esterilizados, $25 \mathrm{~g}$ de cada amostra, em $225 \mathrm{~mL}\left(10^{-1}\right)$ de diluente, água peptonada 0,1\% estéril. A partir destas, foram feitas sucessivas diluições decimais, a partir de $1 \mathrm{~mL}$ diluindo-se em $9 \mathrm{~mL}$ de água peptonada,, em tubos de diluição, conforme Downes \& Ito (2001). Da coalhada cortada, foram feitas diluições até $10^{-7}$ nas $4^{\mathrm{a}}$ e $11^{\mathrm{a}}$ coletas, $10^{-5}$ nas $5^{\mathrm{a}}$ e $7^{\mathrm{a}}$ e $10^{-4}$ na $6^{\mathrm{a}}$. Da coalhada dessorada, foram feitas diluições até $10^{-8}$ na $4^{\text {a }}$ coleta, $10^{-5}$ na $5^{\mathrm{a}}, 10^{-4}$ na $6^{\mathrm{a}}$, $10^{-6}$ na $7^{\text {a }}$ e $10^{-7}$ na $11^{\text {a }}$. Do queijo antes da salga, foram efetuadas diluições até $10^{-8}$ nas $8^{\mathrm{a}}, 9^{\mathrm{a}}$ e $11^{\mathrm{a}}$ coletas e $10^{-9}$ na $10^{\mathrm{a}}$. E finalmente, do queijo após a salga, foram efetuadas diluições até $10^{-9}$ nas $8^{\text {a }}, 10^{\text {a }}$ e $11^{\text {a }}$ coletas e $10^{-8}$ na $9^{\text {a }}$. 


\subsubsection{Amostras de salmoura}

Amostras de aproximadamente $1 \mathrm{~L}$ de salmoura do tanque localizado na câmara de refrigeração, foram retiradas com uma concha de metal esterilizada após homogeneização do tanque. Todas foram colocadas em frascos de vidro esterilizados.

Preparo das amostras de salmoura:

Foram feitas diluições em tubos de diluição a partir de $10 \mathrm{~mL}$ de salmoura em $90 \mathrm{~mL}\left(10^{-1}\right)$ de diluente, água peptonada 0,1\% estéril, e a partir destas foi retirado $1 \mathrm{~mL}$ para diluição em 9 mL de água peptonada e a partir desta sucessivas diluições decimais, conforme Downes \& Ito (2001). Foram efetuadas diluições até $10^{-9}$ na $8^{\text {a }}$ coleta, $10^{-7}$ nas $9^{\mathrm{a}}$ e $11^{\mathrm{a}}$ e $10^{-6}$ na $10^{\mathrm{a}}$.

\subsection{Análises Microbiológicas}

As análises microbiológicas foram realizadas segundo as metodologias indicadas pela legislação vigente, de acordo com Downes \& Ito (2001).

Todos os materiais e meios foram previamente esterilizados em autoclave a $121^{\circ} \mathrm{C}$ por $15 \mathrm{~min}$, com exceção das vidrarias que foram esterilizadas em estufa a $160{ }^{\circ} \mathrm{C}$ por 2 horas.

\subsubsection{Contagem total de microrganismos mesófilos aeróbios}

Em todas as amostras foi feita a contagem total de microrganismos aeróbios mesófilos pelo método de plaqueamento em profundidade, em placas de Petri, utilizando-se o meio de cultura, Ágar Padrão para Contagem - PCA (Merck). Alíquotas de $1 \mathrm{~mL}$ das diluições obtidas em 3.2.1, 3.2.2 e 3.2.3 foram inoculadas, das quais foram utilizadas de 4 a 5 diluições consideradas mais apropriadas, variando de acordo com a 
contaminação da amostra. Após solidificação, as placas foram invertidas e incubadas em estufa incubadora a $35^{\circ} \mathrm{C}$ por $48 \mathrm{~h}$. Após incubação, as placas contendo entre 20 e 200 colônias foram contadas e o resultado foi expresso em UFC por g ou $\mathrm{mL}$ da amostra. Os plaqueamentos foram efetuados em duplicatas.

\subsubsection{Contagem total de microrganismos psicrotróficos aeróbios}

Foi efetuada a contagem total de microrganismos aeróbios psicrotróficos nas amostras de salmoura, queijo antes da salga e queijo após a salga, pelo método de plaqueamento em superfície, em placas de Petri, das diluições obtidas em 3.2.2 (de queijos) e 3.2.3. Utilizou-se de 4 a 5 diluições consideradas mais apropriadas, variando de acordo com a contaminação da amostra. Foram espalhadas alíquotas de 0,1 mL com alça de Drigalsky no meio previamente preparado e solidificado de PCA (Merck) e as placas foram invertidas e incubadas a $7^{\circ} \mathrm{C}$ por 10 dias. Após o período de incubação, as placas contendo entre 20 e 200 colônias foram contadas e o resultado foi expresso em UFC por g ou mL da amostra. Os plaqueamentos foram efetuados em duplicatas.

\subsubsection{Determinação do número mais provável (NMP) de Staphylococcus coagulase positiva}

O procedimento foi adotado somente para as amostras de leite cru pois a alta contaminação por outros microrganismos neste produto impedia a visualização das colônias pelo método de plaqueamento direto em superfície.

Tal método pode ser aplicado tanto para detecção de pequena população de Staphylococcus aureus, quanto para alimentos (crus, não processados) que contêm grande população de espécies competidoras (Silva et al., 1997; Downes \& Ito, 2001). Mostra-se muito seletivo para $S$. aureus e significativo na enumeração de pequenas, médias e altas populações em alimentos naturalmente contaminados (Martin, 1989). 
Foram utilizadas séries de três tubos contendo $10 \mathrm{~mL}$ de caldo Tripticase de Soja (Merck) adicionado de $10 \%$ de $\mathrm{NaCl}$ e de $1 \%$ de piruvato de sódio. Foi inoculado por tubo $1 \mathrm{~mL}$ de leite cru assim como $1 \mathrm{~mL}$ de suas diluições obtidas em 3.2.1 até $10^{-3}$. Foram incubados a $35^{\circ} \mathrm{C}$ por $48 \mathrm{~h}$. Posteriormente foi feito o isolamento dos conteúdos dos tubos por estriagem em placas contendo Ágar BP - Baird-Parker (Merck) previamente solidificado e adicionado de solução de gema de ovo a 50\% com 0,1\% de telurito de potássio. A incubação das placas foi realizada em estufa incubadora a $35^{\circ} \mathrm{C}$ durante 48 h. Foram selecionadas para a contagem, em média cinco por placa, colônias típicas de Staphylococcus, circulares, pretas, pequenas (com no máximo 1,5mm em diâmetro), lisas, convexas, com bordas perfeitas, esbranquiçadas nas bordas, rodeadas por uma zona opaca e/ou halos transparentes, assim como colônias atípicas, sem formação de halo. As colônias selecionadas foram transferidas para tubos com caldo BHI - Brain Heart Infusion (Merck), e foram incubados a $35^{\circ} \mathrm{C}$ por $24 \mathrm{~h}$, para a realização do teste confirmativo da coagulase. O resultado foi expresso em NMP/mL da contagem das colônias em que foram obtidas confirmações das provas descritas a seguir.

\section{a) Coloração de Gram}

A coloração de Gram foi feita de acordo com as seguintes etapas: transferência de uma alçada de cada cultura suspeita da placa (BP) para uma lâmina; esfregaço dessa alçada; fixação do esfregaço na chama do bico de Bunsen; cobertura de toda a lâmina com solução de cristal violeta durante um minuto e desprezo do corante; cobertura da lâmina com lugol durante um minuto e 30 segundos e desprezo do corante; inclinação da lâmina e gotejamento de álcool acetona até o total desprendimento do corante; lavagem da lâmina em água corrente; cobertura com fucsina de Gram por 30 segundos e lavagem da lâmina em água corrente e secagem. Foram observados cocos Gram positivos em forma de cachos.

b) Teste da catalase

Para o teste da catalase, foi transferida uma alçada das colônias suspeitas da placa BP para uma lâmina de vidro e sobre ela adicionada água oxigenada (peróxido de 
hidrogênio) a 3\%. No caso de resultado positivo foi observada imediatamente a formação de bolhas.

c) Teste da coagulase

Foram transferidos 0,2 mL de cada cultura obtida em BHI para tubos de 10x100mm. Foram adicionados em cada tubo 0,5 mL de suspensão salina de Coagulase Plasma-EDTA (plasma de coelho com EDTA) e misturados com movimentos de rotação, sem agitar os tubos, para não interferir na coagulação. Foi feita incubação em banho-maria a $37^{\circ} \mathrm{C}$ e examinada cada hora a formação de coágulo. Conforme a confirmação dos testes, os resultados foram expressos em NMP/g ou mL de acordo com a tabela NMP adequada, consultada de Silva et al. (1997).

\subsubsection{Contagem de Staphylococcus coagulase positiva por plaqueamento direto}

Para todas as amostras, exceto de leite cru, foi realizada a contagem de Staphylococcus pelo plaqueamento em superfície, por meio de semeadura de alíquotas de 0,1 mL com espalhamento com alça de Drigalsky, em placas de Petri de Ágar BP (Merck) previamente solidificado e adicionado de solução de gema de ovo a 50\% com $0,1 \%$ de telurito de potássio, a partir das diluições obtidas até $10^{-3}$. A incubação das placas foi realizada em estufa incubadora a $35^{\circ} \mathrm{C}$ durante $48 \mathrm{~h}$. Colônias típicas com halo e atípicas sem halo foram selecionadas, em média de cinco por placa, para realização das provas descritas em 3.3.3. As colônias selecionadas foram transferidas para tubos com caldo BHI - Brain Heart Infusion (Merck), e foram incubadas a $35^{\circ} \mathrm{C}$ por $24 \mathrm{~h}$, para a realização do teste confirmativo da coagulase. Os resultados foram expressos em UFC/g ou mL. 


\subsubsection{Determinação do número mais provável (NMP) de coliformes totais e fecais}

A contagem dos coliformes fecais foi feita em todas as amostras pelo método dos Tubos Múltiplos ou Número Mais Provável (NMP), com utilização de séries de três tubos contendo Caldo Lauril Sulfato Triptose - LST (Merck), e adição de 1,0 mL das diluições preparadas em 3.2.1, 3.2.2 e 3.3.3. Foram utilizadas de 4 a 5 diluições consideradas mais apropriadas, variando de acordo com a contaminação da amostra. A incubação dos tubos foi realizada em estufa incubadora a $35^{\circ} \mathrm{C}$ por $48 \mathrm{~h}$. Os tubos que apresentaram produção de gás e turvação foram submetidos aos testes confirmativos: para coliformes totais, foi transferida alçada para tubos contendo caldo Verde Brilhante Bile - VB (Oxoid) e feita incubação em estufa a $35^{\circ} \mathrm{C}$ por $48 \mathrm{~h}$; para coliformes fecais foi transferida alçada para tubos contendo caldo Escherichia coli - EC (Merck) e feita incubação em banho-maria a $44,5^{\circ} \mathrm{C}$ por $24 \mathrm{~h}$. Os resultados foram expressos em NMP/g ou mL de acordo com a tabela NMP adequada, consultada de Silva et al. (1997). 


\section{RESULTADOS E DISCUSSÃO}

\subsection{Pasteurização}

A Tabela 5 apresenta os resultados da avaliação nas quatro primeiras coletas.

Tabela 5 - Contagens de microrganismos mesófilos aeróbios, coliformes totais, coliformes fecais e Staphylococcus coagulase positiva das amostras de leite cru e de leite pasteurizado.

\begin{tabular}{|c|c|c|c|c|c|}
\hline Coleta & & $\begin{array}{c}\text { Mesófilos aeróbios } \\
\text { UFC/mL } \\
\left(\log _{10} \mathrm{UFC} / \mathrm{mL}\right)\end{array}$ & $\begin{array}{l}\text { Coliformes totais } \\
\text { NMP/mL } \\
\left(\log _{10} \mathrm{NMP} / \mathrm{mL}\right)\end{array}$ & $\begin{array}{l}\text { Coliformes fecais } \\
\mathrm{NMP} / \mathrm{mL} \quad\left(\log _{10}\right. \\
\mathrm{NMP} / \mathrm{mL})\end{array}$ & $\begin{array}{c}\text { S. coag. + } \\
\text { UFC/mL } \\
\left(\log _{10} \mathrm{UFC} / \mathrm{mL}\right)\end{array}$ \\
\hline \multirow[t]{2}{*}{1} & LC & $2,8 \times 10^{7}(7,45)$ & $>2,4 \times 10^{7}(>7,38)$ & $>2,4 \times 10^{7}(>7,38)$ & PREJUDICADO \\
\hline & LP & $2,3 \times 10^{5}(5,36)$ & $5,3 \times 10^{2}(2,72)$ & $35(1,54)$ & PREJUDICADO \\
\hline \multirow[t]{2}{*}{2} & LC & $1,3 \times 10^{10}(10,11)$ & $1,9 \times 10^{6}(6,28)$ & $4,0 \times 10^{5}(5,60)$ & $39^{a}\left(1,59^{a}\right)$ \\
\hline & LP & $9,4 \times 10^{7}(7,97)$ & $3,3 \times 10^{2}(2,52)$ & $11(1,04)$ & $(1,00)$ \\
\hline \multirow[t]{2}{*}{3} & LC & $5,0 \times 10^{6}(6,70)$ & $1,1 \times 10^{6}(6,04)$ & $1,5 \times 10^{5}(5,17)$ & $>2,4 \times 10^{3 \mathrm{a}}\left(>3,38^{\mathrm{a}}\right)$ \\
\hline & LP & $1,5 \times 10^{5}(5,17)$ & $1,1 \times 10^{4}(4,04)$ & $70(1,84)$ & 1,0 (zero) \\
\hline \multirow[t]{2}{*}{4} & LC & $4,9 \times 10^{6}(6,69)$ & $2,1 \times 10^{5}(5,32)$ & $4,3 \times 10^{4}(4,63)$ & $2,4 \times 10^{3 a}\left(3,38^{a}\right)$ \\
\hline & LP & $1,8 \times 10^{5}(5,25)$ & $23(1,36)$ & $4,0(0,60)$ & <zero) \\
\hline
\end{tabular}

Onde LC = leite cru e LP = leite pasteurizado. ${ }^{\text {a }}$ Expressos em NMP/mL ou $\log _{10} \mathrm{NMP} / \mathrm{mL}$.

A Instrução Normativa $n^{0} 51$ (Brasil, 2002) não prevê limites para microrganismos mesófilos no leite cru tipo $\mathrm{C}$, mas após pasteurização fixa o valor $\mathrm{M}=$ $3,0 \times 10^{5} \mathrm{UFC} / \mathrm{mL}$. Portanto, foi possível evidenciar que na coleta 2, a amostra de leite

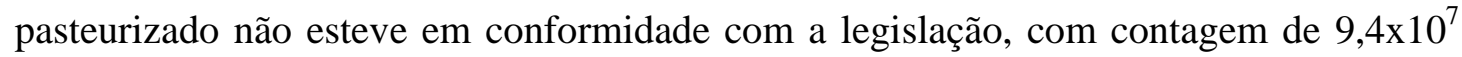
UFC/mL. Nas demais coletas as contagens estiveram muito próximas do limite: de 
2,3×10 $, 1,8 \times 10^{5}$ e $1,8 \times 10^{5} \mathrm{UFC} / \mathrm{mL}$. Tavares (1996), avaliando 48 amostras de leite pasteurizado tipo C comercializado em Piracicaba, encontrou contagens de mesófilos que variaram de $5,2 \times 10^{3}$ a $1,6 \times 10^{7} \mathrm{UFC} / \mathrm{mL}$.

As altas contagens de microrganismos mesófilos no leite cru, apesar de não haver padrão legal, demonstram má qualidade da matéria-prima. As contagens foram sempre superiores a $10^{6} \mathrm{UFC} / \mathrm{mL}$, sendo que na segunda coleta a contagem atingiu o número de $1,3 \times 10^{10}$, valor extremamente elevado. A excessiva presença de microrganismos aeróbios mesófilos reflete a má qualidade bacteriológica do alimento, associada a uma redução na vida útil do produto (Assumpção, 2001).

Figura 6 - Contagens de microrganismos mesófilos aeróbios no leite cru e no

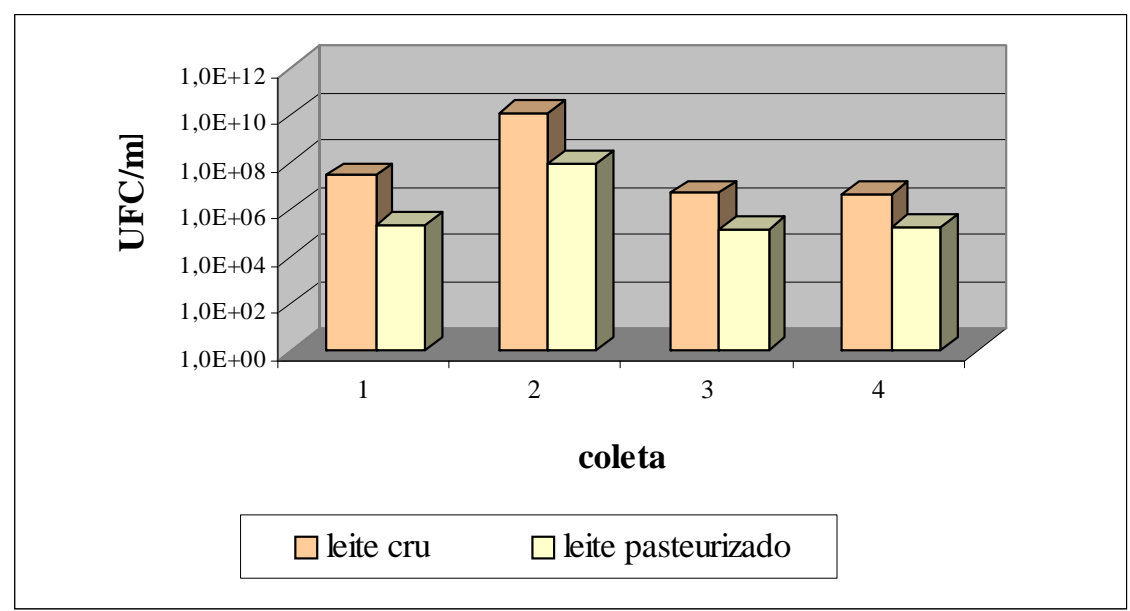

leite pasteurizado nas quatro primeiras coletas, avaliando a pasteurização.

A falta de higiene e a não adoção de princípios e técnicas de garantia sanitária durante a ordenha podem comprometer seriamente a qualidade do leite obtido (Germano \& Germano, 2004). Durante a ordenha, pode haver contaminação significativa através da exposição e do contato do leite com bactérias provenientes do 
úbere, das tetas, do solo, fezes dos animais, das mãos e roupas do ordenhador, das instalações (piso, parede, teto), ordenhadeiras mecânicas, tanques de estocagem ou latões, baldes, panos usados para coar o leite ou secar o úbere (Fernandes et al, 2003). A elevada contagem microbiana no leite cru é um forte indicador de problemas que podem estar ocorrendo durante a ordenha e/ou durante armazenamento e transporte até o laticínio.

A redução na população de mesófilos aeróbios, em ciclos log, na pasteurização, verificada nas análises foi de 2,08 ciclos na coleta 1 , de 2,14 ciclos na coleta 2, de 1,52 na coleta 3 e de 1,44 ciclos na coleta 4, resultando em uma média de 1,80 ciclos log, sem oscilações significativas (desvio padrão de 0,37), e evidenciou homogeneidade do tratamento térmico.

Ajzental et al. (1996), em estudo crítico sobre o processo de pasteurização rápida de leite, demonstraram que a eficácia do processo, aferida em termos da amplitude entre população inicial e final, não é afetada pela presença de populações elevadas de bactérias apatogênicas mesófilas no leite cru . Entretanto, Assumpção (2001), analisando processamento de queijo prato, verificou em sete amostragens de leites crus e pasteurizados uma oscilação de 1,5 a 5,2 ciclos log na redução na contagem total de microrganismos aeróbios mesófilos da pasteurização.

Não há padrões de qualidade microbiológicas para coliformes em leite cru tipo C. De acordo com a RDC nº12 (Brasil, 2001), o valor máximo permitido de coliformes de origem fecal em leite pasteurizado é de $4 \mathrm{NMP} / \mathrm{mL}$. Este mesmo limite consta na Instrução Normativa n51 (Brasil, 2002), para coliformes totais e de 2 NMP/mL para coliformes fecais em leite pasteurizado. Porém, para o leite imediatamente após a pasteurização o limite é de < 0,3 NMP de coliformes a $35^{\circ} \mathrm{C} / \mathrm{mL}$, de acordo com essa Instrução. 


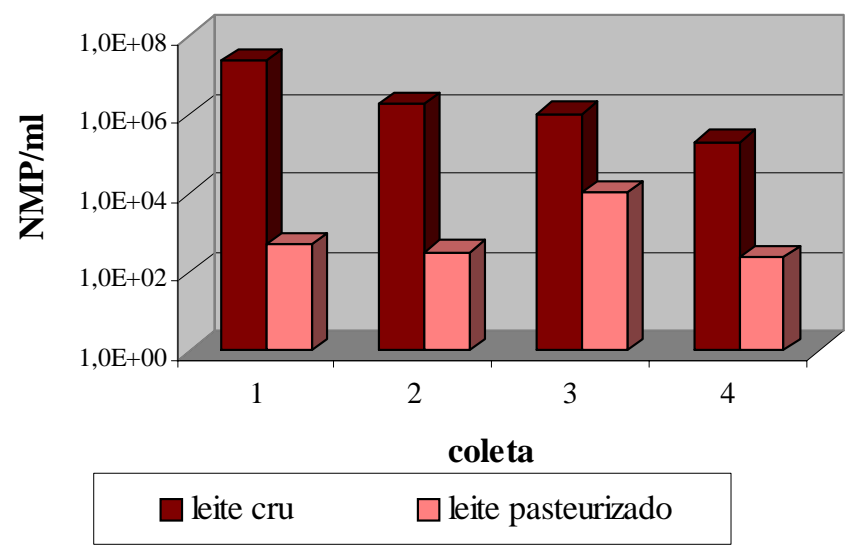

Figura 7 - Contagens de coliformes totais no leite cru e no leite pasteurizado nas quatro primeiras coletas, avaliando a pasteurização.

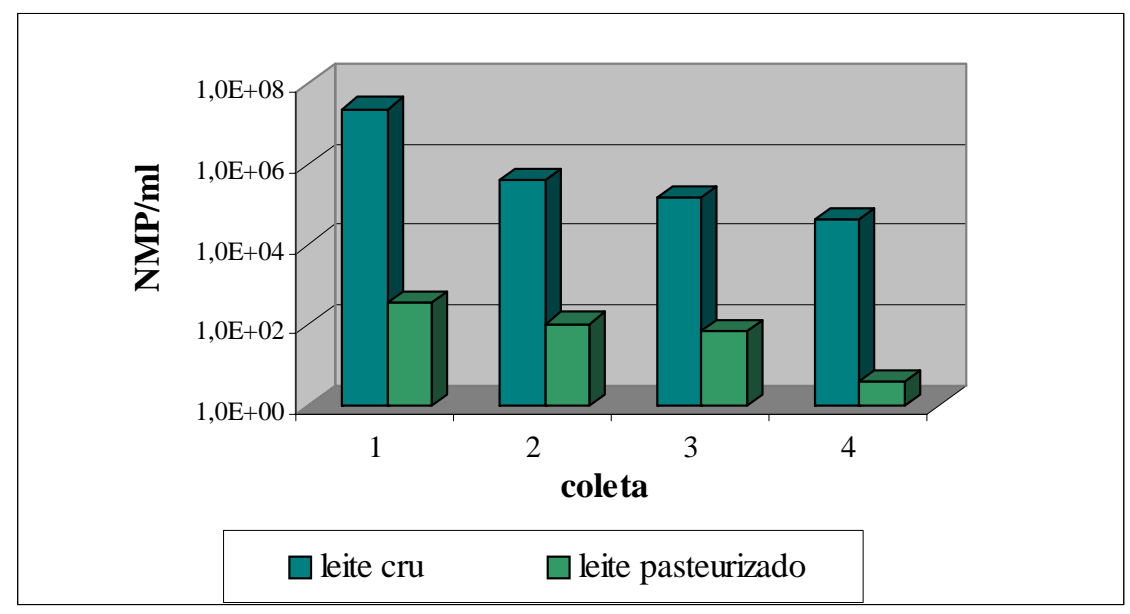

Figura 8 - Contagens de coliformes fecais no leite cru e no leite pasteurizado nas quatro primeiras coletas, avaliando a pasteurização.

Os resultados das análises de coliformes totais encontrados no leite cru foram de $>2,4 \times 10^{7}, 1,9 \times 10^{6}, 1,1 \times 10^{6}$ e $2,1 \times 10^{5} \mathrm{NMP} / \mathrm{mL}$, e de coliformes totais no leite pasteurizado foram de $5,3 \times 10^{2}, 3,3 \times 10^{2}, 1,1 \times 10^{4}$ e 2,3x10 NMP/mL. Os resultados de coliformes fecais encontrados no leite cru foram de $>2,4 \times 10^{7}, 4,0 \times 10^{5}, 1,5 \times 10^{5}$ e $4,3 \times 10^{4} \mathrm{NMP} / \mathrm{mL}$ e de coliformes fecais no leite pasteurizado foram de $3,5 \times 10,1,1 \times 10$, 
7,0x10 e 4,0 NMP/mL. Estes números evidenciam valores acima dos limites estabelecidos, e são indicadores de graves falhas na manipulação, de deficiências na higienização do estabelecimento e equipamentos e problemas relativos à higiene pessoal de manipuladores. Aplicando-se o critério mais rigoroso para leite recém pasteurizado da Instrução Normativa 51 (Brasil, 2002), de contagem de coliformes a $35^{\circ} \mathrm{C}<0,3$ $\mathrm{NMP} / \mathrm{mL}$, todas as amostras seriam condenadas.

Em recente pesquisa, Rizzo-Benato (2004) encontrou valores que variaram de $1,1 \times 10^{2}$ a 2,9x $10^{4} \mathrm{NMP}$ de coliformes totais /mL em 24 amostras de leite pasteurizado tipo C, e ainda que 70,8\% dessas amostras estavam em desacordo com os padrões da Agência Nacional de Vigilância Sanitária - ANVISA (Brasil, 2001) para coliformes fecais.

A presença de coliformes fecais, especialmente de $E$. coli em índices condenatórios, além de mostrar as más condições higiênicas, evidencia, também, a possibilidade do produto veicular outros microrganismos patogênicos ao homem (Pereira et al., 1999).

O grupo de microrganismos coliformes é muito sensível ao processo de pasteurização (Assumpção, 2001). A redução aproximada na população de coliformes totais na pasteurização, em ciclos log, verificada nas análises foi de $>4,65$ ciclos na coleta 1, de 3,76 ciclos na coleta 2, de 2,0 ciclos na coleta 3 e de 3,96 ciclos na coleta 4, resultando em média e desvio padrão aproximados de 3,59 ciclos log e 1,13, respectivamente, mostrando uma heterogeneidade no processo de pasteurização com relação a esse grupo de microrganismo.

A redução aproximada na população de coliformes fecais, em ciclos log, na pasteurização, verificada nas análises foi $>5,83$ ciclos na coleta 1 , de 4,56 ciclos na coleta 2 , de 3,33 ciclos na coleta 3 e de 4,03 ciclos na coleta 4 . A média resultante aproximada foi de 4,44 ciclos log e desvio padrão de 1,06. Devido à 
elevada população inicial, o processo de pasteurização mostrou-se ineficiente, visto que as contagens ultrapassaram os limites estabelecidos na legislação.

Não foram identificados o Staphylococcus coagulase positiva na $1^{\text {a }}$ coleta, pois as placas se apresentaram extremamente cheias de colônias pretas, sem a possibilidade de distinção de colônias típicas. Somente a partir da $2^{\mathrm{a}}$ coleta, com a utilização de caldo seletivo do método do Número Mais Provável para amostras de leite cru é que foi possível enumerá-los. Embora o número não tenha sido tão elevado quanto ao dos demais microrganismos estudados em duas coletas, sua população foi em torno ou maior que $10^{3} \mathrm{NMP} / \mathrm{mL}$ no leite cru, um indicativo de problemas sanitários. Além disso, a microbiota acompanhante capaz de crescer no meio de ágar Baird-Parker era muito elevada, obrigando adaptação da metodologia.

O processo de aquecimento utilizado para pasteurizar o leite destrói o Staphylococcus, mas não destrói qualquer toxina que tenha sido previamente produzida. Sabe-se que as toxinas estafilocócicas são resistentes ao calor e podem permanecer ativas no alimento por um longo período (Carmo et al., 2002).

O leite transportado até a indústria em latões, não era submetido ao resfriamento após a ordenha. Foram verificadas condições precárias dos pisos da plataforma e de muitos latões, que se apresentavam sujos e com riscos, além da posterior lavagem, insuficiente e inadequada. Alguns transportadores apresentavam-se com roupas e mãos sujas e alguns latões chegavam em carroças puxadas por cavalo. Era comum notar no filtro do tanque de recepção, pêlos, fragmentos de insetos e outras sujidades, o que é esperado nesta situação.

Num país de clima tropical como o Brasil, se o leite cru não sofrer refrigeração adequada durante todo tempo até seu consumo, se for transportado em latões sujos e se for misturado com outros de qualidade inferior, o processo 
de pasteurização não fornecerá um produto de boa qualidade, mas apenas o beneficiará (Borges \& Oliveira, 1999).

\subsection{Tanque de coagulação}

A Tabela 6 apresenta os resultados encontrados das coletas 4, 5, 6 e 7 referentes a avaliação da coagulação.

Tabela 6 - Contagens de microrganismos mesófilos aeróbios, coliformes totais, coliformes fecais e Staphylococcus coagulase positiva nas amostras de leite pasteurizado, coalhada cortada e coalhada dessorada.

\begin{tabular}{|c|c|c|c|c|c|}
\hline Coleta & & $\begin{array}{l}\text { Mesófilos aeróbios } \\
\text { UFC/g ( } \log _{10} \text { UFC/g) }\end{array}$ & $\begin{array}{c}\text { Coliformes totais } \\
\text { NMP/g } \\
\left(\log _{10} \mathrm{NMP} / \mathrm{g}\right)\end{array}$ & $\begin{array}{c}\text { Coliformes fecais } \\
\text { NMP/g } \\
\left(\log _{10} \mathrm{NMP} / \mathrm{g}\right)\end{array}$ & $\begin{array}{c}\text { S. coag. }{ }^{+} \\
\text {UFC/g } \\
\left(\log _{10} \text { UFC/g) }\right.\end{array}$ \\
\hline \multirow{3}{*}{4} & LP & $1,8 \times 10^{5 \mathrm{a}}\left(5,25^{\mathrm{a}}\right)$ & $23(1,36)$ & $4,0(0,60)$ & $<1^{\mathrm{a}}\left(<\right.$ zero $\left.^{\mathrm{a}}\right)$ \\
\hline & $\mathrm{CO}$ & $1,2 \times 10^{5}(5,08)$ & $2,4 \times 10^{3}(3,38)$ & $2,4 \times 10^{3}(3,38)$ & $<10(<1)$ \\
\hline & $\mathrm{CD}$ & $8,0 \times 10^{5}(5,90)$ & $2,4 \times 10^{3}(3,38)$ & $2,4 \times 10^{3}(3,38)$ & $20(1,30)$ \\
\hline \multirow{3}{*}{5} & LP & $8,8 \times 10^{3 \mathrm{a}}\left(3,94^{\mathrm{a}}\right)$ & $<3,0^{b}\left(<0,48^{b}\right)$ & $<3,0^{b}\left(<0,48^{b}\right)$ & $<1^{\text {a }}\left(<\right.$ zero $\left.^{\text {a }}\right)$ \\
\hline & $\mathrm{CO}$ & $7,5 \times 10^{4}(4,87)$ & $90(1,95)$ & $90(1,95)$ & $<10(<1)$ \\
\hline & $\mathrm{CD}$ & $6,8 \times 10^{4}(4,83)$ & $2,3 \times 10^{2}(2,36)$ & $9,3 \times 10^{2}(2,97)$ & $<10(<1)$ \\
\hline \multirow{3}{*}{6} & LP & $3,2 \times 10^{4 a}\left(4,50^{a}\right)$ & $>2,4 \times 10^{2 b}\left(>2,38^{b}\right)$ & $>2,4 \times 10^{2 b}\left(>2,38^{b}\right)$ & $<1^{\text {a }}\left(<\right.$ zero $\left.^{\mathrm{a}}\right)$ \\
\hline & $\mathrm{CO}$ & $2,6 \times 10^{5}(5,41)$ & $>2,4 \times 10^{3} \quad(>3,38)$ & $>2,4 \times 10^{3} \quad(>3,38)$ & $<10(<1)$ \\
\hline & CD & $2,5 \times 10^{6}(6,40)$ & $>2,4 \times 10^{4} \quad(>4,38)$ & $>2,4 \times 10^{4} \quad(>4,38)$ & $30 \quad(1,48)$ \\
\hline \multirow{3}{*}{7} & LP & $8,1 \times 10^{3 \mathrm{a}}\left(3,91^{\mathrm{a}}\right)$ & $<0,3^{b}\left(>0,52^{b}\right)$ & $<0,3^{b}\left(>0,52^{b}\right)$ & $<1^{\mathrm{a}}\left(<\right.$ zero $\left.^{\mathrm{a}}\right)$ \\
\hline & $\mathrm{CO}$ & $1,9 \times 10^{6}(6,28)$ & $4,6 \times 10^{3}(3,66)$ & $2,4 \times 10^{2}(2,38)$ & $<10(<1)$ \\
\hline & $\mathrm{CD}$ & $2,0 \times 10^{7}(7,30)$ & $9,3 \times 10^{2}(2,97)$ & $9,3 \times 10^{2}(2,97)$ & $<10(<1)$ \\
\hline
\end{tabular}

Onde LP = leite pasteurizado, $\mathrm{CO}=$ coalhada cortada e $\mathrm{CD}=$ coalhada dessorada. ${ }^{\text {a }}$ Expressos em UFC/mL ou $\log _{10} \mathrm{UFC} / \mathrm{mL} ;{ }^{\text {b }}$ expressos em NMP/mL ou $\log _{10} \mathrm{NMP} / \mathrm{mL}$.

Os valores encontrados de mesófilos aeróbios em UFC/g nas coalhadas

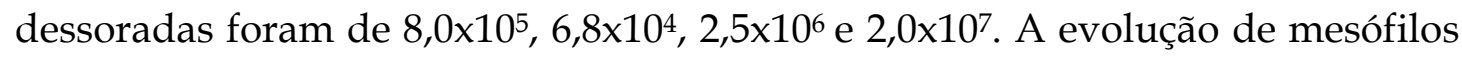


aeróbios no tanque de coagulação nas 4 coletas, do leite pasteurizado até a coalhada dessorada foi de aproximadamente $0,65,0,89,1,89$ e 3,39 ciclos log. E o crescimento na população da coalhada cortada para a coalhada dessorada foi de aproximadamente $0,82,-0,04,0,98$ e 1,02 ciclos log.

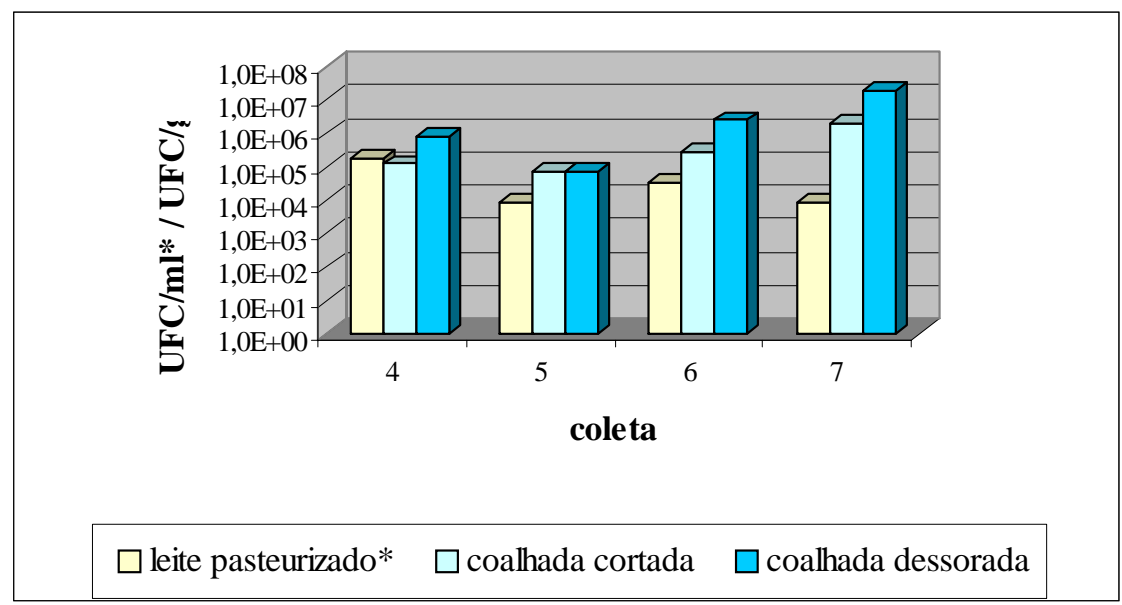

Figura 9 - Contagem de microrganismos mesófilos aeróbicos no leite pasteurizado, na coalhada cortada e na coalhada dessorada nas coletas 4, 5, 6 e 7, avaliando o tanque de coagulação.

Souza et al. (2003) avaliando o crescimento de mesófilos aeróbios no processamento de queijo serrano encontraram um acréscimo em torno de 1,5 e 1,7 ciclos log, nas estações de verão e inverno, respectivamente. Segundo os autores, este acréscimo na população microbiana é um fenômeno normal no processamento do queijo, que se dá em parte pela multiplicação de microrganismos durante a coagulação e em parte pela retenção física destes microrganismos na coalhada quando o soro é expulso. No caso do queijo serrano, o tempo de coleta entre o leite e a coalhada era de aproximadamente $1 \mathrm{~h} 30 \mathrm{~min}$, e neste trabalho o tempo entre as coletas destes produtos levava em média $2 \mathrm{~h} 30 \mathrm{~min}$. O queijo serrano é um queijo de massa crua tradicionalmente produzido no sul do Brasil com leite cru e também sem a utilização de fermento lático. 
O aumento da população de coliformes totais (NMP) encontrado no tanque de coagulação do leite pasteurizado até a coalhada dessorada foi de aproximadamente 2,02 ciclos log, na coleta 4, >1,88 ciclos log, na coleta 5 e >3,49 ciclos log, na coleta 7 . Na coleta 6, não foi possível quantificar devido à elevada contaminação, embora tenha havido indicativo de aumento. Nessa coleta 6 ocorreu um imprevisto na produção, pela qual a coalhada no tanque esperou por mais de 1h30min para ser cortada devido ao remanejamento do funcionário responsável para outras funções naquele dia.

O crescimento da população de coliformes totais, em NMP/g, encontrado no tanque de coagulação da coalhada cortada até a coalhada dessorada foi de 0 e 0,41 ciclos log, nas coletas 4 e 5, respectivamente, e um decréscimo aproximado de 0,69 na coleta 7.

O aumento da população de coliformes fecais encontrado no tanque de coagulação do leite pasteurizado até a coalhada dessorada foi de aproximadamente 2,78 ciclos log, na coleta 4, >2,49 ciclos log, na coleta 5 e >3,49 ciclos log, na coleta 7 . Houve crescimento da população de coliformes fecais no tanque de coagulação da coalhada cortada até a coalhada dessorada de 1,00 e 0,59 ciclos log, nas coletas 5 e 7, respectivamente. Souza et al. (2003) encontraram valores de até 3,7x10 $\mathrm{UFC} / \mathrm{g}$ de coliformes totais e de até $1,8 \times 10^{4} \mathrm{UFC} / \mathrm{g}$ de coliformes fecais em coalhada do queijo serrano.

Observa-se que os valores encontrados de coliformes totais e de fecais se assemelham nas coalhadas cortada e dessorada da coleta 4, na coalhada cortada da coleta 5 e na coalhada dessorada da coleta 7 . Tal fato pode ser explicado pela temperatura de $42^{\circ} \mathrm{C}$ aplicada na coagulação, tornando-se mais seletiva ao grupo de coliformes fecais.

Somente foi encontrado Staphylococcus coagulase positiva nas amostras de coalhada dessorada das coletas 4 e 6, com contagens de 20 e de 30 UFC/g, respectivamente. Isso evidencia presença no tanque, mas com baixa população. 
Os funcionários envolvidos no processo utilizavam luvas de látex, porém estas não cobriam os antebraços, que eram imersos no tanque durante a dessoragem. Por muitas vezes a placa de polietileno que servia para separar a coalhada cortada do soro durante a dessoragem caía e os funcionários inseriam mãos e antebraços no tanque, com soro e coalhada, para recolhê-la e mesmo assim, não ocorreu aumento da população de Staphylococcus.

Havia sempre tanques abertos cheio de soro situados ao lado do tanque de coagulação. Este soro era sempre deixado exposto por mais de um dia e exalava forte odor. Segundo Furtado et al. (2003), deve-se minimizar a transferência de ar de áreas contaminadas (recepção de matéria-prima e ingredientes, armazenamento de suprimentos, etc.) para áreas de processamento e embalagem. 


\subsection{Salga}

Os resultados encontrados das coletas 8, 9 e10, referentes às amostras da etapa salga, estão demonstrados na Tabela 7.

Tabela 7 - Contagens de microrganismos mesófilos aeróbios, psicrotróficos aeróbios, coliformes totais, coliformes fecais e Staphylococcus coagulase positiva nas amostras de queijos antes e após a salga e na própria salmoura.

\begin{tabular}{|c|c|c|c|c|c|c|}
\hline Coleta & & $\begin{array}{c}\text { Mesófilos } \\
\text { aeróbios } \\
\text { UFC/g } \\
\left.\text { (log } \log _{10} \mathrm{UFC} / \mathrm{g}\right)\end{array}$ & $\begin{array}{l}\text { Psicrotróficos } \\
\text { aeróbios } \\
\text { UFC/g } \\
\left(\log _{10} \mathrm{UFC} / \mathrm{g}\right)\end{array}$ & $\begin{array}{l}\text { Coliformes } \\
\text { totais NMP/g } \\
\left(\log _{10} \mathrm{NMP} / \mathrm{g}\right)\end{array}$ & $\begin{array}{c}\text { Coliformes } \\
\text { fecais NMP/g } \\
\left(\log _{10} \mathrm{NMP} / \mathrm{g}\right)\end{array}$ & $\begin{array}{c}\text { S. coag. }+ \\
\text { UFC/g } \\
\left(\log _{10} \text { UFC/g) }\right.\end{array}$ \\
\hline \multirow{3}{*}{8} & SM & $\begin{array}{c}4,2 \times 10^{6} \mathrm{a} \\
\left(6,62^{\mathrm{a}}\right)\end{array}$ & $\begin{array}{c}1,6 \times 10^{6} \mathrm{a} \\
\left(6,20^{\mathrm{a}}\right)\end{array}$ & $\begin{array}{c}>2,4 \times 10^{4} b \\
\left(>4,38^{b}\right)\end{array}$ & $\begin{array}{c}>2,410^{4} \mathrm{~b} \\
\left(>4,38^{\mathrm{b}}\right)\end{array}$ & $<1^{\text {a }}\left(<\right.$ zero $\left.^{a}\right)$ \\
\hline & QA & $4,6 \times 10^{8}(8,66)$ & $1,0 \times 10^{9}(9,00)$ & $\begin{array}{c}>2,4 \times 10^{4} \\
(>4,38)\end{array}$ & $\begin{array}{c}>2,4 \times 10^{4} \\
(>4,38)\end{array}$ & $<10(<1)$ \\
\hline & $\mathrm{QP}$ & $1,0 \times 10^{9}(9,00)$ & $1,2 \times 10^{9}(9,08)$ & $\begin{array}{c}>2,4 \times 10^{4} \\
(>4,38)\end{array}$ & $\begin{array}{c}>2,4 \times 10^{4} \\
(>4,38)\end{array}$ & $<10(<1)$ \\
\hline \multirow{3}{*}{9} & SM & $\begin{array}{c}2,9 \times 10^{6 \mathrm{a}} \\
\left(6,46^{\mathrm{a}}\right)\end{array}$ & $\begin{array}{c}8,0 \times 10^{4 a} \\
\left(4,90^{\mathrm{a}}\right)\end{array}$ & $\begin{array}{l}2,3 \times 10^{4 b} \\
\left(>4,36^{b}\right)\end{array}$ & $\begin{array}{l}2,3 \times 10^{4 b} \\
\left(>4,36^{b}\right)\end{array}$ & $<1^{\mathrm{a}}\left(<\right.$ zero $\left.^{\mathrm{a}}\right)$ \\
\hline & QA & $8,0 \times 10^{9}(9,00)$ & $3,9 \times 10^{7}(7,59)$ & $\begin{array}{c}>2,4 \times 10^{6} \\
(>6,38)\end{array}$ & $\begin{array}{c}>2,4 \times 10^{6} \\
(>6,38)\end{array}$ & $\begin{array}{c}2,0 \times 10^{3} \\
(3,30)\end{array}$ \\
\hline & QP & $\begin{array}{c}2,9 \times 10^{10} \\
(10,46)\end{array}$ & $3,5 \times 10^{8}(8,54)$ & $\begin{array}{c}>2,4 \times 10^{6} \\
(>6,38)\end{array}$ & $\begin{array}{c}>2,4 \times 10^{6} \\
(>6,38)\end{array}$ & $\begin{array}{c}1,0 \times 10^{3} \\
(3,00)\end{array}$ \\
\hline \multirow{3}{*}{10} & SM & $\begin{array}{c}1,0 \times 10^{6 a} \\
\left(6,00^{\mathrm{a}}\right)\end{array}$ & $\begin{array}{c}1,4 \times 10^{5 a} \\
\left(5,14^{a}\right)\end{array}$ & $\begin{array}{c}1,1 \times 10^{6 b} \\
\left(6,04^{b}\right)\end{array}$ & $\begin{array}{c}1,1 \times 10^{6 b} \\
\left(6,04^{b}\right)\end{array}$ & $60^{\mathrm{a}}\left(1,78^{\mathrm{a}}\right)$ \\
\hline & QA & $4,0 \times 10^{8}(8,60)$ & $3,1 \times 10^{6}(6,49)$ & $9,3 \times 10^{5}(5,97)$ & $2,3 \times 10^{5} \quad(5,36)$ & $<10(<1)$ \\
\hline & $\mathrm{QP}$ & $7,8 \times 10^{9}(9,89)$ & $7,0 \times 10^{5}(5,84)$ & $\begin{array}{c}>2,4 \times 10^{8} \\
(>8,38)\end{array}$ & $\begin{array}{c}7,5 \times 10^{6} \\
(6,87)\end{array}$ & $<10(<1)$ \\
\hline
\end{tabular}

Onde $\mathrm{SM}=$ salmoura, $\mathrm{QA}=$ queijo antes da salga e $\mathrm{QP}=$ queijo pós salga. ${ }^{\mathrm{a}}$ Expressos em $\mathrm{UFC} / \mathrm{mL}$ ou $\log _{10} \mathrm{UFC} / \mathrm{mL}$; ${ }^{b}$ expressos em NMP/mL ou $\log _{10} \mathrm{NMP} / \mathrm{mL}$. 
De acordo com o Regulamento de Inspeção Industrial e Sanitária dos Produtos de Origem Animal (Brasil, 1997a) é proibido o emprego de salmouras turvas, sujas, alcalinas, com cheiro amoniacal, fermentadas ou inadequadas por qualquer outra razão, mas é permitida a recuperação dessas salmouras após fervura e filtração, a juízo da Inspeção Federal. O presente regulamento não estabelece critérios microbiológicos para salmouras empregadas na fabricação de queijos. A salmoura da indústria apresentava aspecto turvo, coloração amarelo-esverdeada e odor característico de queijo.

Os resultados encontrados na salmoura referentes às contagens de mesófilos aeróbios de três coletas foram de $4,2 \times 10^{6}, 2,9 \times 10^{6}$ e $1,0 \times 10^{6} \mathrm{UFC} / \mathrm{mL}$, resultando em

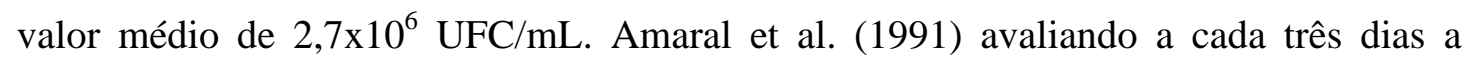
salmoura empregada na salga de queijos Minas Frescal desde o primeiro dia até o $21^{\circ}$

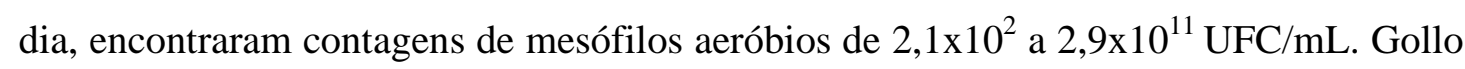
et al. (2003) encontraram contagens de $2,2 \times 10^{6}$ e de $1,0 \times 10^{4} \mathrm{UFC} / \mathrm{mL}$ em salmoura utilizada para salga de queijos mussarela e prato e sugerem procedimentos semanais de monitoramento, abrangendo contagem total de aeróbios mesófilos e controle organoléptico na salmoura (cor e odor).

Segundo Furtado (1991), sempre que a contagem global da salmoura exceder $10^{5}$ UFC/mL é necessária sua correção e recuperação que envolvem: reajuste do teor de sal; correção da acidez titulável a $0,2 \%(\mathrm{~m} / \mathrm{v})$ de ácido lático; redução da carga microbiana por tratamento térmico ou por meio de produtos químicos como o peróxido de hidrogênio (130 volumes), à base de 200-300 mL por 1000 L de salmoura ou como o hipoclorito de sódio, à razão de $500 \mathrm{~mL}$ por $1000 \mathrm{~L}$ de salmoura; seguindo a recuperação por fervura por injeção direta de vapor por 1 h no mínimo, seguida de resfriamento e decantação à temperatura ambiente.

De acordo com um funcionário da indústria, a fervura e a adição de peróxido de hidrogênio, em proporção maior, são feitas, porém tudo indica que a periodicidade dessa manutenção é inadequada, além de também não haver controle por meio uma contagem global prévia e reajuste correto e controlado do teor de sal. 
Os resultados das contagens de psicrotróficos aeróbios na salmoura nas três coletas foram de $1,6 \times 10^{6}, 8,0 \times 10^{4}$ e $1,4 \times 10^{5} \mathrm{UFC} / \mathrm{mL}$, resultando em valor médio de 6,1x10 $\mathrm{UFC} / \mathrm{mL}$. De acordo com Santos \& Genigeorgis (1981), o aumento de microrganismos mesófilos durante a salmouragem decorre da transferência dos microrganismos dos queijos para salmoura.

Rosa (2004), avaliando o queijo Minas frescal da mesma indústria de laticínios, adquirido diretamente sob encomenda, encontrou a composição físico-química apresentada na Tabela 8.

Tabela 8 - Parâmetros físico-químicos do queijo Minas frescal.

\begin{tabular}{cc}
\hline Parâmetros & Valores \\
\hline PH & 6,40 \\
Gordura (\%) & 20,50 \\
Gordura no extrato seco (\%) & 54,60 \\
Umidade (\%) & 62,50 \\
Proteína bruta (\%) & 12,40 \\
Cinzas (\%) & 1,86 \\
Acidez (\%) & 0,281 \\
\hline
\end{tabular}

Fonte: Rosa (2004).

Os valores de $\mathrm{pH}$, acidez e umidade do queijo Minas frescal são propícios ao crescimento de diversos microrganismos, inclusive de muitos patógenos.

As seguintes contagens médias de mesófilos aeróbios (UFC/g) nos queijos antes da salga foram verificadas: $4,6 \times 10^{8} ; 8,0 \times 10^{9} ; 4,0 \times 10^{8}$. E nos queijos após a salga foram: $1,0 \times 10^{9} ; 2,9 \times 10^{10} ; 7,8 \times 10^{9}$. Estes resultados mostram um acréscimo de 0,34, de 0,56 e de 1,29 ciclos log nos queijos após a salga, com relação a esse grupo de microrganismos. 
As seguintes contagens médias de psicrotróficos aeróbios (UFC/g) nos queijos antes da salga foram verificadas: $1,0 \times 10^{9} ; 3,9 \times 10^{7} ; 3,1 \times 10^{6}$. E nos queijos após a salga foram: $1,2 \times 10^{9} ; 3,5 \times 10^{8} ; 7,0 \times 10^{5}$. Estes resultados mostram um acréscimo de 0,08 e de 0,95 ciclos log e um decréscimo de 0,65 ciclos log desse grupo de microrganismos após a salga nos queijos. Rosa (2004), avaliando amostras do queijo Minas frescal do mesmo estabelecimento, encontrou aproximadamente 3,0×10 $10^{6}$ UFC de mesófilos aeróbios/g, e $4,7 \times 10^{5}$ de psicrotróficos aeróbios/g. Psicrotróficos em altas contagens produzem substâncias indesejáveis ao produto por causa de suas atividades proteolíticas e lipolíticas (Silveira et al., 1998).

Os valores de coliformes totais encontrados nas salmouras foram de $>2,4 \times 10^{4}$, $2,3 \times 10^{4}$ e $1,1 \times 10^{6} \mathrm{NMP} / \mathrm{g}$, e coincidentemente os mesmos encontrados para coliformes fecais. Amaral et al. (1991) encontraram valores de 7,8×10 ${ }^{12} \mathrm{NMP}$ de coliformes totais e fecais/100ml em salmouras utilizadas na salga de queijo Minas frescal em seu $21^{\circ}$ dia de

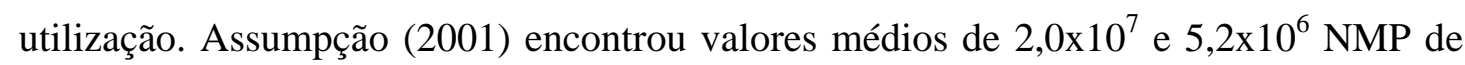
coliformes totais e fecais $/ 100 \mathrm{ml}$, respectivamente, em salmoura utilizada na produção de queijo prato. De acordo com a Portaria 518 (Brasil, 2004 b), a água destinada ao consumo humano deve em $100 \mathrm{~mL}$ acusar ausência de E. coli e coliformes termotolerantes.

Muito embora, não se tenha conseguido quantificar por exato a maioria dos coliformes totais e fecais das amostras de queijo antes e após a salga devido à elevada contaminação, que superou as diluições estimadas, os valores mostram-se bem acima dos estipulados pelas legislações para este tipo de queijo que são de $5 \times 10^{2}$ coliformes de origem fecal/g (Brasil, 2001) e de $1 \times 10^{4}$ coliformes totais/g e $5 \times 10^{3}$ coliformes de origem fecal/g (Brasil, 1996), visto que, o queijo pós salga ainda iria ser embalado e

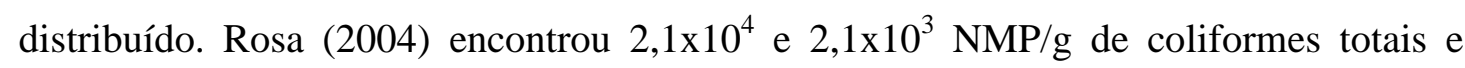
fecais, respectivamente, no queijo Minas frescal produzido na indústria objeto desta pesquisa. 


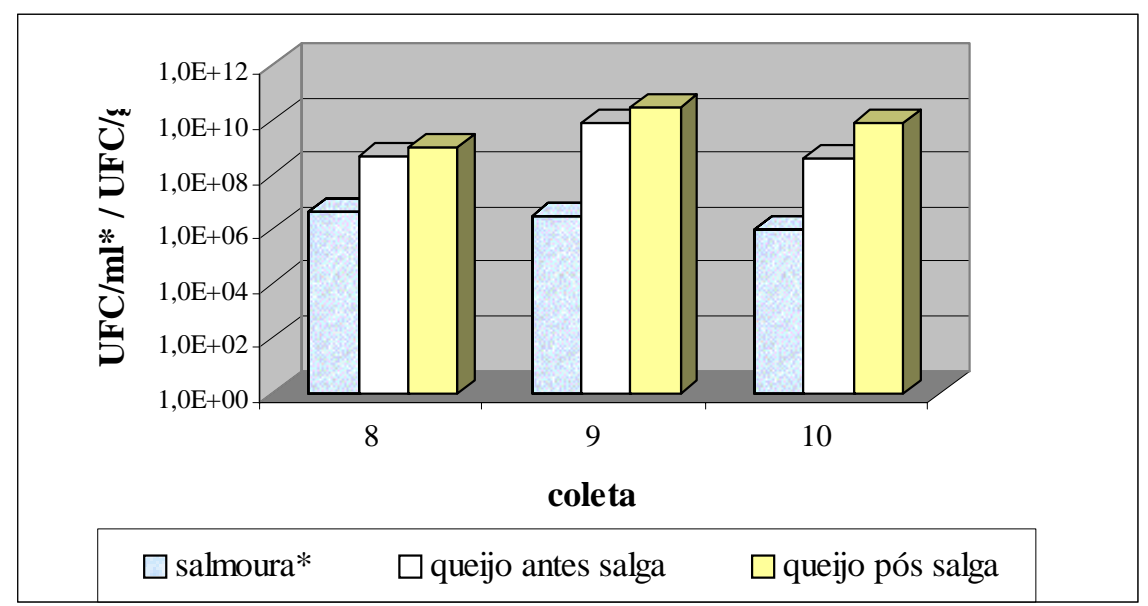

Figura 10 - Contagens de microrganismos mesófilos aeróbios na salmoura, no queijo antes da salga e no queijo pós salga nas coletas 8, 9 e 10, avaliando a salga.

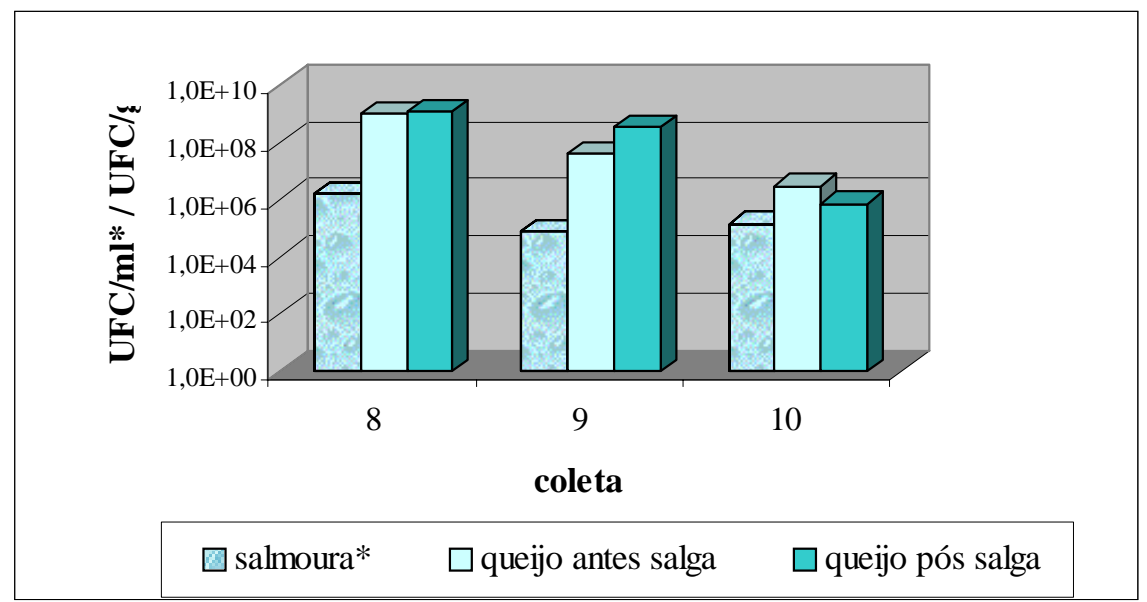

Figura 11 - Contagens de microrganismos psicrotróficos aeróbios na salmoura, no queijo antes da salga e no queijo pós salga nas coletas 8, 9 e 10, avaliando a salga.

A presença de Staphylococcus coag. posit. nas salmouras pode estar relacionada com a manipulação a que são submetidos os queijos e à transferência dos microrganismos dos queijos para a salmoura, durante o processo de salga. A presença desses microrganismos nas salmouras pode acarretar a contaminação de partidas de queijos, e havendo cepas produtoras de enterotoxinas, pode, embora potencialmente, 
representar riscos de saúde aos consumidores (Amaral et al, 1992). Foram encontradas $60 \mathrm{UFC} / \mathrm{mL}$ de $S$. coag. posit. na salmoura apenas na coleta 10 . E na coleta $\mathrm{n}^{\circ} 9$, foram encontrados $2,0 \times 10^{3}$ e $1,0 \times 10^{3}$ UFC/g nos queijos antes e após a salga, respectivamente.

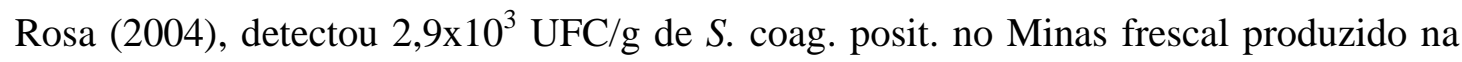
indústria em estudo.

O queijo pode ser contaminado em várias etapas da fabricação, dentre elas, na salmouragem, que é um ponto crítico importante. A concentração de $\mathrm{NaCl}$ comumente usada na salmoura não reduz a atividade de água para valores que inibem completamente o desenvolvimento microbiano. Além disso, seu enriquecimento com vários elementos provenientes do próprio queijo, como, ácido lático, nitrogênio, sais minerais, do $\mathrm{NaCl}$ e da água proporcionam condições favoráveis à sobrevivência e multiplicação de diversos tipos de microrganismos deteriorantes e patogênicos (Casalis et al., 1969). 


\subsection{Amostragem completa ao longo da linha}

Os resultados da coleta $\mathrm{n}^{\circ} 11$ referentes às amostras coletadas ao longo da linha, constituintes de um mesmo lote, estão representados na Tabela 9.

Tabela 9 - Contagens de microrganismos mesófilos aeróbios, psicrotróficos aeróbios, coliformes totais, coliformes fecais e Staphylococcus coagulase positiva das amostras da coleta $\mathrm{n}^{\mathrm{o}} 11$.

\begin{tabular}{|c|c|c|c|c|c|}
\hline & $\begin{array}{c}\text { Mesófilos } \\
\text { aeróbios UFC/g } \\
\left(\log _{10} \mathrm{UFC} / \mathrm{g}\right)\end{array}$ & $\begin{array}{l}\text { Psicrotróficos } \\
\text { aeróbios } \\
\text { UFC/g } \\
\left(\log _{10} \mathrm{UFC} / \mathrm{g}\right)\end{array}$ & $\begin{array}{c}\text { Coliformes totais } \\
\text { NMP/g } \\
\left(\log _{10} \mathrm{NMP} / \mathrm{g}\right)\end{array}$ & $\begin{array}{c}\text { Coliformes fecais } \\
\text { NMP/g } \\
\left(\log _{10} \mathrm{NMP} / \mathrm{g}\right)\end{array}$ & $\begin{array}{c}\text { S. coag. }+ \\
\text { UFC/g } \\
\left(\log _{10} \text { UFC/g) }\right.\end{array}$ \\
\hline $\mathrm{LC}$ & $1,6 \times 10^{6 \mathrm{a}}\left(6,20^{\mathrm{a}}\right)$ & n.r. & $2,4 \times 10^{5 b}\left(5,38^{b}\right)$ & $\begin{array}{c}<3,0 \times 10^{3 \mathrm{~b}} \\
\left(<3,48^{\mathrm{b}}\right)\end{array}$ & $\begin{array}{c}1,1 \times 10^{2 b} \\
\left(2,04^{b}\right)\end{array}$ \\
\hline LP & $5,6 \times 10^{4 a}\left(4,75^{a}\right)$ & n.r. & $0,4^{b}\left(-0,39^{b}\right)$ & $<0,3^{\mathrm{b}} \quad\left(<-0,52^{\mathrm{b}}\right)$ & $<1^{\mathrm{a}}\left(<\right.$ zero $\left.^{\mathrm{a}}\right)$ \\
\hline $\mathrm{CO}$ & $2,0 \times 10^{6}(6,30)$ & n.r. & $1,1 \times 10^{3}(3,04)$ & $93 \quad(1,97)$ & $<10(<1)$ \\
\hline CD & $2,4 \times 10^{5}(5,38)$ & n.r. & $1,1 \times 10^{5}(5,04)$ & $2,1 \times 10^{3}(3,32)$ & $<10(<1)$ \\
\hline QA & $2,8 \times 10^{9}(9,45)$ & $5,4 \times 10^{7}(7,73)$ & $>2,4 \times 10^{10}(>10,38)$ & $1,1 \times 10^{8}(8,04)$ & $<10(<1)$ \\
\hline QP & $1,1 \times 10^{10}(10,04)$ & $3,1 \times 10^{6}(6,49)$ & $>2,4 \times 10^{11}(>11,38)$ & $>2,4 \times 10^{9} \quad(>9,38)$ & $<10(<1)$ \\
\hline SM & $1,2 \times 10^{7 \mathrm{a}}\left(7,08^{\mathrm{a}}\right)$ & $7,8 \times 10^{5 \mathrm{a}}\left(5,89^{\mathrm{a}}\right)$ & $>2,4 \times 10^{9} \mathrm{~b}\left(>9,38^{\mathrm{b}}\right)$ & $1,1 \times 10^{7 b}\left(7,04^{b}\right)$ & $<1^{\mathrm{a}}\left(<\right.$ zero $\left.^{\mathrm{a}}\right)$ \\
\hline
\end{tabular}

Onde LC = leite cru, LP = leite pasteurizado, $\mathrm{CO}$ = coalhada cortada, $\mathrm{CD}$ = coalhada dessorada, $\mathrm{SM}=$ salmoura, $\mathrm{QA}=$ queijo antes da salga e $\mathrm{QP}=$ queijo pós salga. ${ }^{\mathrm{a}}$ Expressos em UFC/mL ou $\log _{10} \mathrm{UFC} / \mathrm{mL} ;{ }^{b}$ expressos em NMP/mL ou $\log _{10} \mathrm{NMP} / \mathrm{mL}$; n.r. = não realizada.

Avaliando o crescimento de mesófilos aeróbios nesta coleta, foi verificado que o leite cru apresentou contagens de $1,6 \times 10^{6} \mathrm{UFC} / \mathrm{mL}$, e teve reduzida essa população na pasteurização para 5,6 x 10 4 UFC/mL, ou 1,45 ciclos log. Na coagulação foi notado um aumento da população de 1,55 ciclos log, do leite pasteurizado até a coalhada cortada e depois um decréscimo de 0,92 desta para a dessorada, chegando a uma contagem de $2,4 \times 10^{5} \mathrm{UFC} / \mathrm{g}$. A população cresceu muito até o dia seguinte, quando foi efetuada a 
salga, atingindo contagens bem altas de $2,8 \times 10^{9}$ e $1,1 \times 10^{10} \mathrm{UFC} / \mathrm{g}$ nos queijos antes e após a salga, respectivamente, demonstrando aumento de 4,66 ciclos log da coalhada dessorada até o queijo depois da salga. A salmoura apresentou população também elevada de $1,2 \times 10^{7}$ de UFC/mL.

Quando se analisa o processamento de queijo Minas frescal, observa-se que a única etapa na qual ocorre eliminação dos perigos microbiológicos é a pasteurização, o único ponto crítico de controle. Esta etapa ocorre no início e contaminações após este processo estão sujeitas a acontecer ao longo da linha, conforme atestam os resultados obtidos neste trabalho.

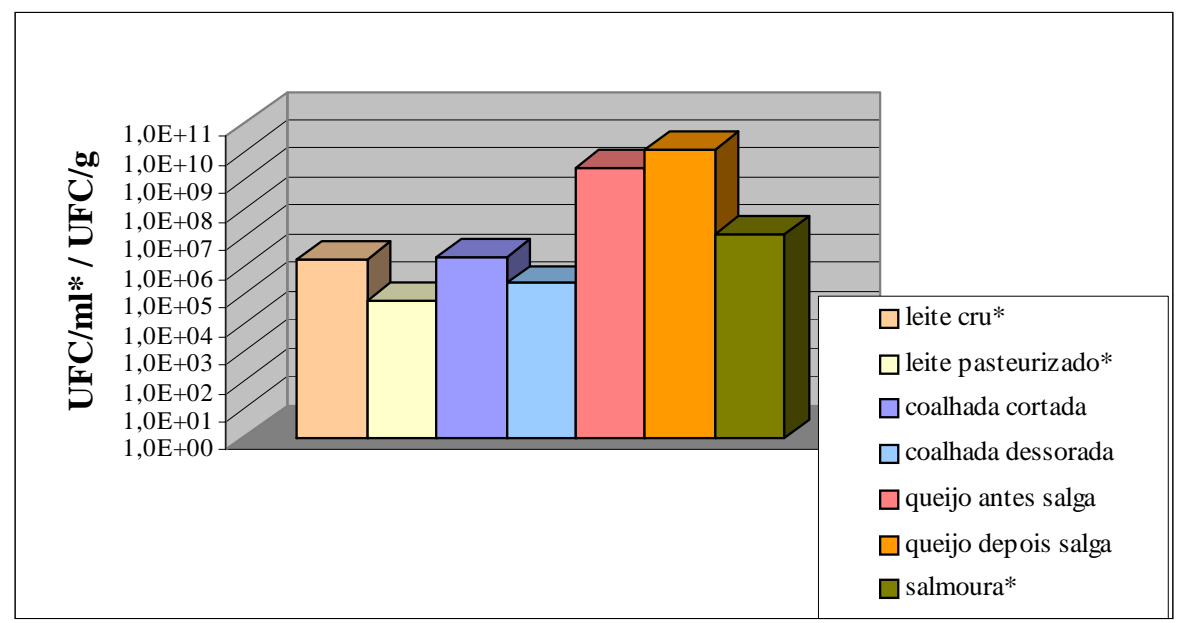

Figura 12 - Contagens de microrganismos mesófilos aeróbios na coleta 11, avaliando toda linha de produção.

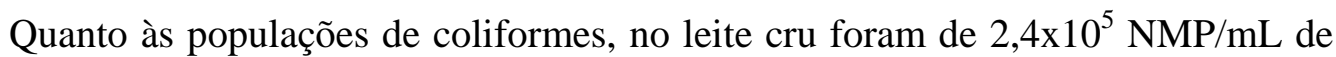
totais e de $<3,0 \times 10^{3} \mathrm{NMP} / \mathrm{mL}$ de fecais. Estas foram reduzidas na pasteurização a 0,4 (5,77 ciclos $\log$ ) e $<0,3$ ( $>4$ ciclos $\log ) \mathrm{NMP} / \mathrm{mL}$. Neste caso o leite pasteurizado apresentou qualidade microbiológica satisfatória, estando dentro dos limites estabelecidos pelas legislações. Porém esses microrganismos tiveram crescimento muito

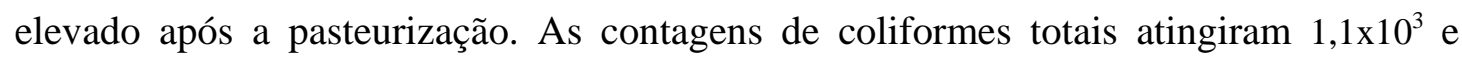


$1,1 \times 10^{5} \mathrm{NMP} / \mathrm{g}$ nas coalhadas cortada e dessorada, revelando um aumento de 5,77 ciclos $\log$ do leite pasteurizado até o produto a ser enformado. Na salga estes números continuaram a crescer demasiadamente e a população de coliformes totais nos queijos antes e após a salga chegaram a $>2,4 \times 10^{10}$ e $>2,4 \times 10^{11} \mathrm{NMP} / \mathrm{g}$, um crescimento de $>6,34$ ciclos log da coalhada dessorada até o produto final. Avaliando o crescimento da população de coliformes totais do leite pasteurizado até o queijo após a salga, foi encontrado o valor de 11,77 ciclos log.

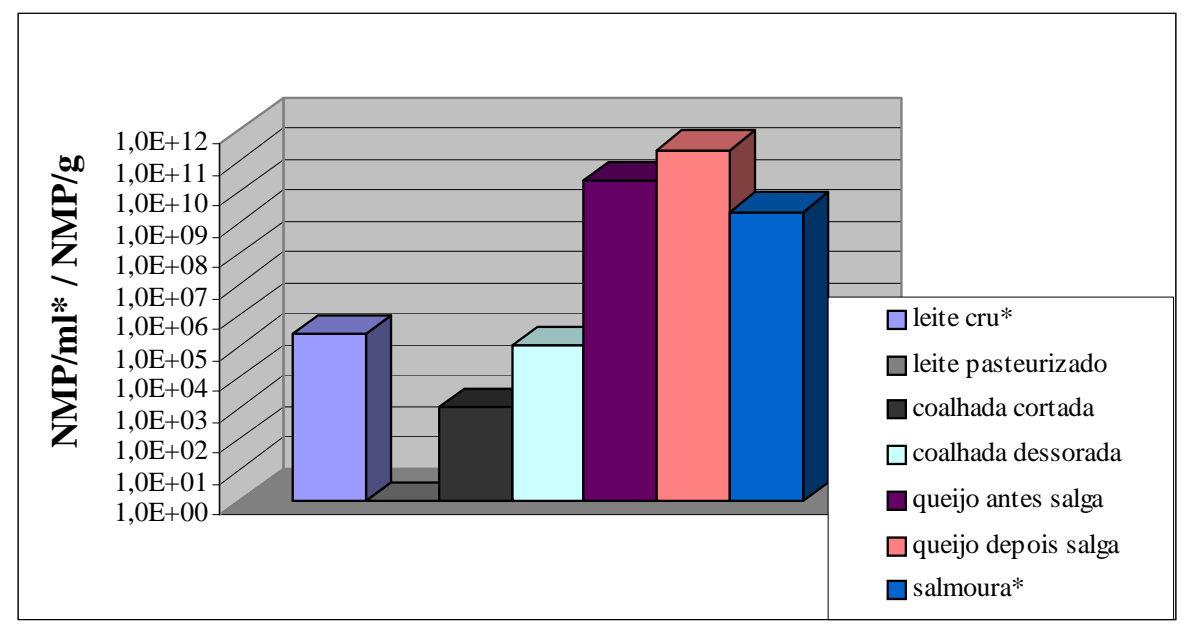

Figura 13 - Contagens de coliformes totais na coleta 11, avaliando toda linha de produção.

A população de coliformes fecais após pasteurização foi crescendo de $93 \mathrm{NMP} / \mathrm{g}$ na coalhada cortada para $2,1 \times 10^{3} \mathrm{NMP} / \mathrm{g}$ na coalhada dessorada, o que demonstra aumento de $>3,84$ ciclos log do leite pasteurizado até a coalhada dessorada. Os queijos antes e após a salga apresentaram contagens de $1,1 \times 10^{8}$ e $>2,4 \times 10^{9} \mathrm{NMP} / \mathrm{g}$, respectivamente, sendo notado aumento $>6,06$ ciclos log da coalhada dessorada até o queijo salgado, e ainda, um aumento $>9.68$ ciclos log do leite pasteurizado até o queijo após a salga. Novamente não foi possível quantificar por exato os coliformes fecais dos queijos e os coliformes totais das amostras de queijo antes da salga devido à elevada 
contaminação, que superou as diluições estimadas. Porém fica bem claro que esses valores mostram-se bem acima dos estipulados pelas legislações e que a indústria oferece ao mercado um produto altamente contaminado.

A amostra de salmoura apresentou as mais altas contagens nesta última coleta, com $>2,4 \times 10^{9} \mathrm{NMP} / \mathrm{mL}$ de coliformes totais e $1,1 \times 10^{7} \mathrm{NMP} / \mathrm{mL}$ de coliformes fecais. Esta água não vinha recebendo, portanto, nenhum tipo de manutenção ou controle e a microbiota contaminante veio aumentando através da transferência dos queijos para a mesma, em contínua utilização.

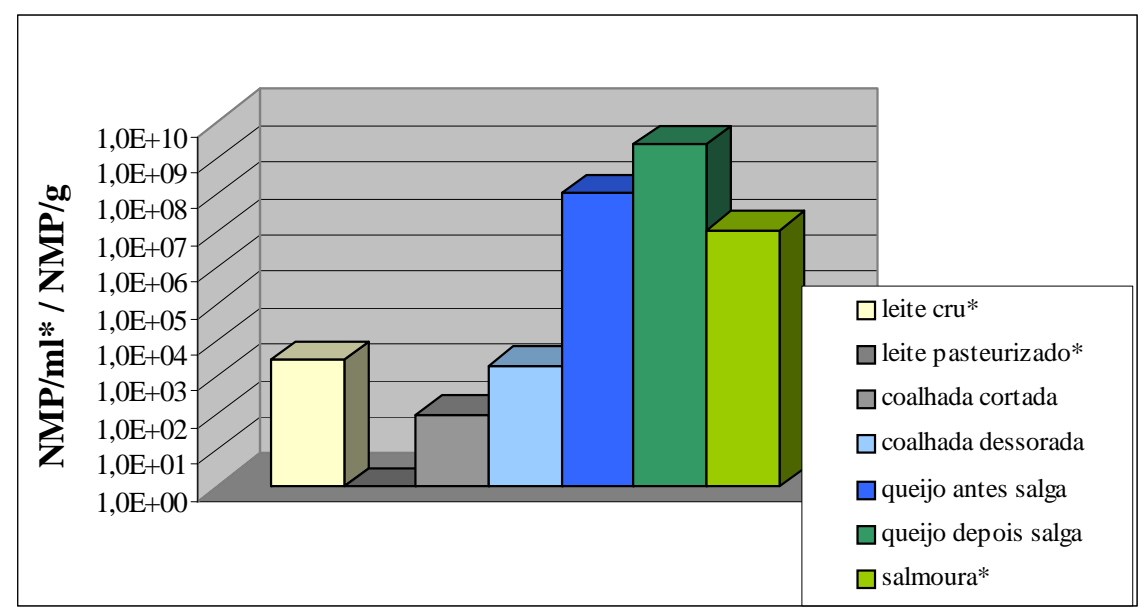

Figura 14 - Contagens de coliformes fecais na coleta 11, avaliando toda linha de produção.

Nesta coleta, percebe-se claramente a recontaminação por coliformes totais e fecais após a pasteurização e alta proliferação ao longo da linha. E quanto à população de Staphylococcus coag. posit. somente foi encontrada no leite cru, $1,1 \times 10^{2} \mathrm{NMP} / \mathrm{mL}$, sendo eliminada na pasteurização e não foi mais detectada ao longo da linha.

A contaminação microbiológica na indústria de alimentos representa um sério perigo para a saúde do consumidor. As indústrias de laticínios, pela própria matériaprima que utilizam e pelo alto teor de umidade nos locais de produção, são particularmente susceptíveis a essa contaminação (Perry, 2004). 
Tendo em vista que a competitividade industrial associada à conscientização do consumidor tem exigido das indústrias alimentícias um maior controle sobre seus alimentos processados, recomenda-se, além do controle microbiológico do produto final, a implantação do programa de qualidade Análise de Perigos e Pontos Críticos de Controle - APPCC (Hoffman et al., 2002).

Um alimento produzido, processado e usado de acordo com o sistema APPCC, dá alto grau de certeza de sua segurança e qualidade microbiológica (APPCC, 1997). A operação das linhas de produção de fábricas com os princípios do APPCC se tornou atualmente obrigatória em muitos países e, embora o processo de fabricação de queijos seja muito complexo, a introdução do APPCC pode assegurar, em uma boa extensão, o controle dos processos de fabricação e, deste modo, se obter produtos finais seguros e de alta qualidade (Bintsis \& Papademas, 2002).

Na presente pesquisa foi observado que durante a produção, os funcionários utilizavam luvas de látex, tipo cirúrgicas, mas praticamente não havia uma rotina de troca das mesmas e lavagem das mãos. O lavatório destinado à higienização das mãos dos funcionários sempre se encontrava coberto por camada de poeira e não havia sanitizante. Os pisos em muitos locais não apresentavam rejunte, havia água e muito soro empoçados, soro na câmara onde se procedia a salga e em diversos pontos da linha. Não havia isolamento da produção com a área externa permitindo entrada de pragas; as portas da sala de pasteurização e coagulação ficavam abertas com saída para a plataforma de recepção do leite e havia outra porta próxima à sala de embalagem que comunicava com a área externa.

Para Furtado et al. (2003), o ar pode veicular microrganismos indesejáveis para a área de processamento, através de vapor condensado, aerossóis e outras partículas suspensas. $\mathrm{O}$ ar externo que entra na planta deve ser filtrado de forma a não permitir a entrada de microrganismos. 
O Serviço de Inspeção Federal, ausente, não tomou providências para garantir a qualidade higiênico-sanitária da indústria estudada e do queijo Minas frescal fabricado. Melhorias nos procedimentos de sanificação, na planta física da fábrica e medidas para garantir boas práticas de fabricação precisam ser aplicadas na indústria, bem como maior controle de qualidade na recepção do leite. 


\section{CONCLUSÕES}

Diante dos resultados do presente trabalho e das condições nas quais se apresentava a indústria pode ser concluído que:

- O leite cru recebido apresentou elevadas contagens de microrganismos mesófilos e de bactérias coliformes totais e fecais, indicando más condições higiênico-sanitárias.

- No leite cru, também a população de Staphylococcus coagulase positiva foi elevada. Além disso, a microbiota contaminante prejudicou o isolamento desse microrganismo, havendo necessidade de adaptação da metodologia.

- A pasteurização reduziu a população microbiana de acordo com o esperado. Contudo o produto pasteurizado na maioria das vezes esteve fora dos padrões exigidos pela legislação brasileira.

- Após a redução obtida na pasteurização, as contagens de bactérias mesófilas e do grupo coliforme se elevaram nas etapas de coagulação e corte da coalhada na fabricação do queijo, evidenciando recontaminação e/ou proliferação microbiana.

- Na etapa de coagulação e corte a contagem de coliformes totais foi confirmada como coliformes fecais, sendo similares ambas as populações. A elevada temperatura de coagulação $\left(42^{\circ} \mathrm{C}\right)$ aparentemente favorece o aumento da população de coliformes fecais.

- Na etapa da salga, a população de microrganismos mesófilos totais e coliformes fecais no queijo também aumentou. A salmoura apresentou alta contaminação por coliformes totais e fecais, estando imprópria para o uso.

- Os resultados evidenciaram que a pasteurização foi eficiente na redução da população microbiana, mas que as condições após operação contribuíram para que o produto final apresentasse contagens de microrganismos mesófilos, coliformes totais 
e fecais muito superiores ao do leite pasteurizado inicial no processo. Evidencia-se a necessidade de severo controle higiênico-sanitário ao longo da linha de produção de queijo e a importância do controle biológico e da utilização de métodos como Análise de Perigos e Pontos Críticos de Controle (APPCC) na indústria estudada. 


\section{REFERÊNCIAS BIBLIOGRÁFICAS}

ABREU, L.R. de. Tecnologia de leite e derivados. Lavras: UFLA/ FAEPE, 1999. 215p.

AJZENTAL, A.; RICCETTI, R.V.; KRUTMAN, F.K.; CORTÊS, J.A. Influência da taxa de contaminação inicial do leite sobre o resultado da pasteurização. Leite e Derivados, n. 29, p.41-54, jul./ago. 1996.

ALMEIDA FILHO, E.S.; NADER FILHO, A. Ocorrência de coliformes fecais e Escherichia coli em queijo tipo Minas frescal de produção artesanal, comercializado em Poços de Caldas, MG. Higiene Alimentar, v.16, n.102/103, p.71-73, nov./dez. 2002.

ALMEIDA FILHO, E.S.; LINDNER, A.L.; ALMEIDA, D.S.; SIGARINI, C.O.; FERREIRA, M.B. Perfil microbiológico de queijo tipo Minas frescal, de produção artesanal e inspecionada, comercializado no município de Cuiabá, MT. Higiene Alimentar, v.16, n.92/93, p.51-58, jan./fev. 2002.

ALVES, V.S.; COSTA, P.S. da; ROBBS, P.G.; FAVARIN, V. Avaliação tecnológica sobre a produção artesanal ed queijo Minas frescal, utilizando glucona-delta-lactona (GDL), e sua importância no controle de Staphylococcus aureus. Higiene Alimentar, v.17, n.107, p.27-31, abr. 2003.

AMARAL, L.A. do; NADER FILHO, A.; IARIA, S.T. Variação das características físico-químicas e microbiológicas das salmouras durante sua utilização na salga de queijos tipo Minas “frescal”. Revista de Microbiologia, v.22, n.2, p.136-140, 1991. 
AMARAL, l.A. do; NADER FILHO, A.; IARIA, S.T.; FERRO, J.A. Variação das características físico-químicas e microbiológicas das salmouras empregadas na salga de queijos tipo mussarela durante o período de sua utilização. Revista Saúde Pública, v.26, n.1, p.41-45., fev. 1992.

APPCC na qualidade e segurança microbiológica de alimentos: análises de perigos e pontos críticos de controle para garantir a qualidade e a segurança microbiológica de alimentos. São Paulo: Varela, 1997. 377p.

ASSUMPÇÃO, E.G. Identificação dos pontos de contaminação microbiológica ao longo do processamento de queijo prato: estudo de caso. Lavras, 2001. 77p. Dissertação (M.S.) - Universidade Federal de Lavras.

BAIRD-PARKER, A.C. The Staphylococci: an introduction. Journal of Applied Bacteriology, v.19, 1S-8S, 1990.

BEHMER, M.L.A. Tecnologia do leite. 15.ed. São Paulo: Nobel, 1991, 320p.

BINTSIS, T.; PAPADEMAS, P. Microbiological quality of white-brined cheeses: a review. International Journal of Dairy Technology, v.55, n.3, p. 113-20, Aug. 2002.

BONASSI, I.A.; GOLDONI, J.S.; LIMA, U.A. Efeito na acidificação direta com ácido lático na fabricação do queijo tipo Minas. Revista Brasileira de Tecnologia, v.9, p.73-78, 1978.

BORGES, S.F.; OLIVEIRA, J.S. O nosso leite de cada dia. Informe Agropecuário, v.13, n.155, p.3-5, 1999.

BRASIL. Ministério da Agricultura, Pecuária e Abastecimento. Departamento de Inspeção de Produtos de Origem Animal - DIPOA. Regulamento da inspeção industrial e sanitária de produtos de origem animal (RIISPOA). Diário Oficial da União, Brasília, 04 jun., 1997a, 214p.0

BRASIL. Ministério da Agricultura, Pecuária e Abastecimento. Instrução Normativa nº de 1 de março de 2004. Diário Oficial da União, Brasília, 5 mar. 2004 a. Seção I, p.5. 
BRASIL. Ministério da Saúde. Norma de qualidade da água para consumo humano e seu padrão de potabilidade. Portaria n518, Diário Oficial da União, Brasília, 26 mar. 2004 b, Seção I, pág. 266 -70.

BRASIL. Ministério da Saúde. Agência Nacional de Vigilância Sanitária (ANVISA). Resolução - RDC no 12 de 2 de janeiro de 2001. Regulamento técnico sobre padrões microbiológicos para alimentos. Diário Oficial da União, Brasília, 02 jan. 2001.

BRASIL. Ministério da Agricultura, Pecuária e Abastecimento. Regulamento técnico de produção, identidade e qualidade do leite tipo a, do leite tipo b, do leite tipo c, do leite pasteurizado e do leite cru refrigerado e o regulamento técnico da coleta de leite cru refrigerado e seu transporte a granel. Instrução Normativa $n^{0} 51$. Diário Oficial da União, Brasília, 20 set. 2002. Seção I, p.13 - 68.

BRASIL. Ministério da Agricultura, Pecuária e Abastecimento. Regulamento técnico de identidade e qualidade de queijos. Portaria $n^{0} 146$. Diário Oficial da União $n^{\circ} 172$, Brasília, 11 mar. 1996.

BRASIL. Ministério da Agricultura, Pecuária e Abastecimento. Regulamento técnico para fixação de identidade e qualidade de queijo minas frescal. Portaria nº352. Diário Oficial da União, Brasília, 08 set. 1997 b. Seção I, p.13 - 68.

CAMPOS, D.C. de; PRADO FILHO, L.G. do. Queijo: breve histórico e principais características. Piracicaba: ESALQ, 2001. 59p. (NAPMA, 11)

CARMO, L.S. do. Produção e purificação em grande escala das enterotoxinas estafilocócicas SEA, SEB, SEC2, SED e toxina TSST-1 para uso em ensaios imunoenzimáticos. Belo Horizonte, 2001. Tese (Doutorado) - Universidade Federal de Minas Gerais.

CARMO, L.S. do; DIAS, R.S.; LINARDI, V.R.; SENA, M.J. de; SANTOS, D.A. dos; FARIA, M.E. de; PENA, E.C.; JETT, M.; HENEINE, L.G. Food poisoning due to enterotoxigenic strains of Staphylococcus present in Minas cheese and raw milk in Brazil. Food Microbiology, v.19, p.9-14, 2002. 
CARVALHO, E.P. de. Microbiologia de alimentos. Lavras: UFLA/FAEPE, 1999. $76 p$.

CARVALHO, E.P. de. Microbiologia de alimentos, saúde pública e legislação. Lavras: UFLA/FAEPE, 2001. 171p.

CASALIS, J.; LUQUET, F.M.; ROSSIER, F. Sur trataiment des saumures de fromagerie par les rayons ultraviolets. Lait, v. 483/84, p.134-145, 1969.

COUSIN, M.A.; JAY, J.M.; VASAVADA, P.C. Psycrotrofic microorganisms. In: DOWNES, F.P.; ITO, K. 4ed. Compendium of methods for the microbiological examination of foods. Washington: American Public Health Association, 2001. cap.13, p.159-166.

COSTA, F.N.; LIMA., R.M.S.; RABELO, R.N. Comportamento frente à ação de antimicrobianos de cepas de Staphylococcus coagulase positiva, Escherichia coli e Bacillus cereus isolados de derivados lácteos. Higiene Alimentar, v.16, n.92/93, p. 80-83, jan./fev. 2002.

DELAZARI, I.; LEITÃO, M.F.F.; GERALDINI, A.N.; EIROA, M.N.U.; VALLE, J.L.E. Desenvolvimento de Staphylococcus aureus e produção de enterotoxina em queijo tipo Minas. Coletânea do Instituto de Tecnologia de Alimentos, v.9, p163174, 1978.

DOWNES, F.P.; ITO, K. 4ed. Compendium of methods for the microbiological examination of foods. Washington: American Public Health Association, 2001. 676p.

EMPRESA DE PESQUISA AGROPECUÁRIA DE MINAS GERAIS (EPAMIG). Os queijos na fazenda. Rio de Janeiro: Globo, 1987. 219p. (Coleção do Agricultor Laticínios).

FERNANDES, A.R.; SILVA, C.A.B. da; MOSQUIM, M.C.A. Resfriamento do leite na propriedade rural. In: SILVA, C.A.B. da; FERNANDES, A.R. Projetos de empreendimentos agroindustriais: produtos de origem animal. Viçosa: UFV, 2003. 308p. 
FIGUEIREDO, R.M. PRP: Programa de redução de patógenos: SSOP: padrões e procedimentos operacionais de sanitização; manual de procedimentos e desenvolvimento. São Paulo: R:M: Figueiredo, 1999. 164p. (Coleção Higiene dos Alimentos, 1).

FRANCO, B.D.G.M.; LANDGRAF, M. Microbiologia dos alimentos. São Paulo: Atheneu, 1996. 182p.

FOOD AND DRUG ADMINISTRATION (FDA). Bacteriological analytical manual. 8ed. Gaithersburg : AOAC International, 1995.

FUNDAÇÃO CENTRO TECNOLÓGICO DE MINAS GERAIS (CETEC). Manual para fabricação de laticínios. Belo Horizonte, 1985. 73p.

FURTADO, M.M. A arte e a ciência do queijo. 2. ed. São Paulo: Globo, 1991. 297p.

FURTADO, M.M. Principais problemas dos queijos: causas e prevenção. São Paulo: Fonte Comunicações, 1999. 176p

FURTADO, M.M.; MOSQUIM, M.C.A.; FERNADES, A.R.; SILVA, C.A.B. da. Laticínios diversificados. In: SILVA, C.A.B. da; FERNANDES, A.R. Projetos de empreendimentos agroindustriais: produtos de origem animal. Viçosa: UFV, 2003. 308p.

FURTADO, M.M; SOUZA, H.M.de; MUNCK, A.V. A fabricação do queijo Minas frescal sem o emprego de culturas láticas. Revista do Instituto de Laticínios Cândido Tostes, v.35, n.207, p.15-21, jan/fev. 1980a.

FURTADO, M.M; WOLFSCHOON-POMBO, A.F.; MUNCK, A.V; SOUZA, H.M.de. Estudo conclusivo à respeito da fabricação do queijo Minas frescal por diferentes processos. Revista do Instituto de Laticínios Cândido Tostes, v.35, n.208, p.1316, mar/abr. 1980b.

FUEYO, J.M.; MARTÍN, M.C.; GONZÁLEZ-HEVIA, M.C.; MENDOZA, M.C. Enterotoxin production and DNA fingerprinting in Staphylococcus aureus isolated from human and food sample. Relation between genetic types and enterotoxin. International Journal of Food Microbiology, v.67, p.139-145, 2001. 
GERMANO, P.M.L.; GERMANO, M.I.S. Higiene e vigilância sanitária de alimentos. São Paulo: Varela, 2004. 630p.

GOMES, H.A.; GALLO, C.R. Ocorrência de Staphylococcus aureus e produção de enterotoxinas por linhagens isoladas a partir de leite cru, leite pasteurizado tipo c e queijo "Minas frescal” comercializados em Piracicaba-SP. Ciência e Tecnologia de Alimentos, v.15 , n.2, p.158-161, jul./dez. 1995.

GOMES, M.A. Modernização do sistema de inspeção sanitária federal de leite e derivados e os programas de segurança alimentar. In: PORTUGAL, J.A.B.; NEVES, B.S.; OLIVEIRA, A.C.S. de; SILVA, P.H.F. da; BRITO, M.A.V.P. Segurança alimentar na cadeia do leite. Juiz de Fora - MG: CT/ILCT - EPAMIG, 2002. p.115-179.

GOLLO, R.; CANSIAN, R.L.; VALDUGA, E. Identificação de alguns pontos críticos de controle no processamento dos queijos prato e mussarela. Brazilian Journal of Food Technology, v.6, n.1, p. 43-51, jan./jun. 2003.

HAYES, P.R.. Microbiologia e higiene de los alimentos. Zaragoza: Acribia, 1993. Cap.3, p.97-102: Produtos lacteos.

HITCHINS, A.D.; HARTMAN, P.A; TODD, E.C.D. Coliforms - Eschericchia coli and its toxins. In: VANDERZANT, C.; SPLITTSTOESSER, D. F. 3.ed. Compendium of methods for the microbiological examination of foods. Washington: American Public Health Association, 1992. Cap.24, p.325-369.

HOFFMAN, F.L.; SILVA, J.V. da; VINTURIM, T.M. Qualidade microbiológica de queijos tipo “Minas frescal”, vendidos em feiras livres na região de São José do Rio Preto, SP. Higiene Alimentar, v.16, n.96, p. 69-76, mai. 2002.

INTERNATIONAL COMISSION ON MICROBIOLOGICAL SPECIFICATIONS FOR FOODS (ICMSF). Técnicas de análisis microbiológico. 2ed. Zaragoza: Acribia, 1982. 431p. (Micro-organismos de los Alimentos, 1). 
INTERNATIONAL COMISSION ON MICROBIOLOGICAL SPECIFICATIONS FOR FOODS (ICMSF). Characteristics of microbial pathogens. London: Chapman \& Hall, 1996. 513p. (Micro-organisms in Foods, 5).

ISEPON, J.S.; OLIVEIRA, A.J. Influência do emprego de culturas láticas nas características do queijo tipo Minas frescal. Ciência e Tecnologia de Alimentos, v.15, n.1, p.1-5, jan./jun. 1995.

KABUKI, D.Y. Rastreamento de Listeria monocytogenes em indústrias processadoras de queijo frescal tipo latino, nos Estados Unidos da América, empregando a subtipagem molecular. Campinas, 2004. 145p. Tese (Doutorado) - Faculdade de Engenharia de Alimentos, Universidade Estadual de Campinas.

LEITE, R.L. Avaliação da qualidade microbiológica de queijos "Minas frescal” e “Minas padrão” elaborados com leite proveniente de vacas com mastite sub-clínica. Lavras, 2000. 68p. Dissertação (M.S.) - Universidade Federal de Lavras.

LOURENÇO NETO, J.P.M. Minas-frescal: uso de culturas láticas como alternativa de melhoria de qualidade. Indústria de Laticínios, v.4, n.22, p. 76-79, jul./ago. 1999.

MANDIL, A.; MORAIS, V.A.D.; PEREIRA, M.L.; FAGUNDES, J.M.S.; CARMO, L.S.; CORREIA, M.G.; CASTRO, E.P.; GOMEZ, M.J.V.M. Staphylococcus aureus em queijos tipo “Minas”. Ciência e Tecnologia de Alimentos, v.2, n.2, p.233-41, 1982.

MARTIN, S.E. Detection of injured Staphylococcus aureus from foods. In: RAY, B. Injured index and pathogenic bacteria. Boca-Raton: CRC Press, 1989. Cap.5, p.133-145.

MORTON, R.D. Aerobic plate count. In: DOWNES, F.P.; ITO, K. 4ed. Compendium of methods for the microbiological examination of foods. Washington: American Public Health Association, 2001. Cap.7, p.63-67. 
MOSSEL, D.A.A.; GARCIA, B.M. Microbiologia de los alimentos. Zaragoza: Acribia, 1988. 375p.

MUTUKUMIRA, A.N.; FERESU, S.B.; NARVHUS, J.A.; ABRAHAMSEN, R.K. Chemical and microbiological quality of raw milk produced by smallholder farmers in Zimbabwe. Journal of Food Protection, v.59, n.9, p. 984-987, Set. 1996.

NASCIMENTO, M.G.F. do; NASCIMENTO, E.R. do; CUNHA, C.P. da; CORBIA, A. C.G. Estudo transversal sobre alguns fatores de risco na contaminação natural de coliformes fecais em queijos Minas frescal. Higiene Alimentar, v.15, n.866, p.5559, jul. 2001.

OMAIRI, L. Avaliação da qualidade e identidade do queijo Minas frescal comercializado na cidade de Campinas - SP. Campinas, 2002. 71p. Dissertação (Mestrado) - Universidade Estadual de Campinas.

OLIVEIRA, C.A.F. de; MORENO, J.F.G.; MISTIER, L.; GERMANO, P.M.L. Características físico-químicas e microbiológicas de queijos Minas frescal e mussarela, produzidos em algumas fábricas de laticínios do estado de São Paulo. Higiene Alimentar, v.12, n.55, p.31-35, mai./jun. 1998.

PEREIRA, M.L.; GASTELOIS, M.C. A.;BASTOS, E.M.A.F.; CAIAFFA, W.T.; FALEITO, E.S.C. Enumeração de coliformes fecais e presença de Salmonella sp. em queijo Minas. Arquivo Brasileiro de Medicina Veterinária, v.51, n.5, p.427-431, 1999.

PEREIRA, M.L.; LARA, M.A. de; DIAS, R.S.; CARMO, L.S. do. Intoxicação por Staphylococcus aureus provocada por queijo “tipo Minas”. Revista de Microbiologia, v.22, n.4, p.349-350, 1991.

PERRY, K.S.P. Queijos: aspectos químicos, bioquímicos e microbiológicos. Química Nova, v.27, n.2, p.293-300, 2004. 
PINTO, P.S.A.; GERMANO, M.A.I.; GERMANO, P.M.L. Queijo Minas: problema emergente da vigilância sanitária. Higiene Alimentar, v.10, n.44 , p.23-27, jul./ago. 1996.

PRATA, L.F. Fundamento de ciência do leite. Jaboticabal: Faculdade de Ciências Agrárias e Veterinária, 1998. 119p.

RAPINI, L.S.; SOUZA, R.M.B.; CERQUEIRA, M.M.O.P.; SOUZA, M.R. Qualidade microbiológica da água de propriedades leiteiras situadas na região metropolitana de Belo Horizonte (MG). Revista do Instituto de Laticínios Cândido Tostes, v.58, n.333, p.95-98, jul./ago. 2003.

RIZZO-BENATO, R.T. Qualidade microbiológica do leite e do sorvete de massa de uma indústria de pequeno porte do município de Piracicaba - SP. Piracicaba, 2004. 62p. Dissertação (Mestrado) - Escola Superior de Agricultura “Luiz de Queiroz”, Universidade de São Paulo.

ROSA, V.P. da. Efeitos da atmosfera modificada e da irradiação sobre as características microbiológicas, físico-químicas e sensoriais do queijo Minas frescal. Piracicaba, 2004. 141p. Dissertação (Mestrado) - Escola Superior de Agricultura "Luiz de Queiroz”, Universidade de São Paulo.

SANTOS, A.L. Comportamento de Staphylococcus aureus em queijo Minas frescal fabricado com leite cru. Lavras, 2004. 54p. Dissertação (M.S.) - Universidade Federal de Lavras.

SANTOS, E.C.; GENIGEORGIS, C. Survival and growth of Staphylococcus aureus in commercially manufactured brazillian Minas cheese. Journal of Food Protection, v.44, p. 177-184, 1981.

SANTOS, E.S.; CARVALHO, E.P.; ABREU, L.R. Psicrotróficos: consequências de sua presença em leite e queijos. Boletim da Sociedade Brasileira de Ciência e Tecnologia de Alimentos, v.33, n.2, p.129-138, jul./dez. 1999.

SANTOS, M.T.M. dos. Efeito do tratamento térmico do leite na qualidade do queijo Minas. Viçosa, 1990. 53p. Dissertação (M.S.) - Universidade Federal de Viçosa. 
SILVA, I.M.M.; ALMEIDA, R.C.C.; ALVES, M.A.O.; ALMEIDA, P.F. Occurrence of Listeria spp. In critical control points and the environment of Minas frescal cheese processing. International Journal of Food Microbiology, v.81, p.241-48, 2003.

SILVA, N.; JUNQUEIRA, V.C.A.; SILVEIRA, N.F.A. Manual de métodos de análises microbiológicas de alimentos. São Paulo: Varela, 1997. 295p.

SILVEIRA, I.A; CARVALHO, E.P.; TEIXEIRA, D. Influência de microrganismos psicrotróficos sobre a qualidade do leite refrigerado. Uma revisão. Higiene Alimentar , v.12, n.55, p. 21-28, mai./jun. 1998.

SNEATH, P.H. ed. Bergey's manual of systematic bacteriology. Baltimore: Wiliams \& Wilkim, 1986. v.2, p.999-1013.

SOUZA, C.F.V. de; ROSA, T.D.; AYUB, M.A.Z. Changes in the microbiological and physicochemical characteristics of serrano cheese during manufacture and ripening. Brazilian Journal of Microbiology, v.34, p.260-266, 2003.

TAVARES, S.G. Avaliação das condições microbiológicas de leite pasteurizado tipos A, B, C, comercializados na cidade de Piracicaba, SP. Piracicaba, 1996. 84p. Dissertação (Mestrado) - Escola Superior de Agricultura “Luiz de Queiroz”, Universidade de São Paulo.

VANDERZANT, C.; SPLITTSTOESSER, D. F. Compendium of methods for the microbiological examination of foods. 4ed. Washington: APHA, 1992. 1.219p.

WENDPAP, L.L.; ROSA, O. O. Presença de Staphylococcus aureus em queijo Minas consumido no município de Cuiabá-MT. Higiene Alimentar, v.7, n.27, p.23-29, ago. 1993. 